IZA DP No. 5696

Job Loss in the Great Recession:

Historical Perspective from the

Displaced Workers Survey, 1984-2010

Henry S. Farber

May 2011 


\title{
Job Loss in the Great Recession: Historical Perspective from the Displaced Workers Survey, 1984-2010
}

\author{
Henry S. Farber \\ Princeton University, \\ NBER and IZA
}

\author{
Discussion Paper No. 5696 \\ May 2011 \\ IZA \\ P.O. Box 7240 \\ 53072 Bonn \\ Germany
}

Phone: +49-228-3894-0

Fax: +49-228-3894-180

E-mail: iza@iza.org

Any opinions expressed here are those of the author(s) and not those of IZA. Research published in this series may include views on policy, but the institute itself takes no institutional policy positions.

The Institute for the Study of Labor (IZA) in Bonn is a local and virtual international research center and a place of communication between science, politics and business. IZA is an independent nonprofit organization supported by Deutsche Post Foundation. The center is associated with the University of Bonn and offers a stimulating research environment through its international network, workshops and conferences, data service, project support, research visits and doctoral program. IZA engages in (i) original and internationally competitive research in all fields of labor economics, (ii) development of policy concepts, and (iii) dissemination of research results and concepts to the interested public.

IZA Discussion Papers often represent preliminary work and are circulated to encourage discussion. Citation of such a paper should account for its provisional character. A revised version may be available directly from the author. 
IZA Discussion Paper No. 5696

May 2011

\section{ABSTRACT}

\section{Job Loss in the Great Recession: Historical Perspective from the Displaced Workers Survey, 1984-2010*}

The Great Recession from December 2007 to June 2009 is associated with a dramatic weakening of the labor market from which the labor market is now only slowly recovering. The unemployment rate remains stubbornly high and durations of unemployment are unprecedentedly long. I use data from the Displaced Workers Survey (DWS) from 1984-2010 to investigate the incidence and consequences of job loss from 1981-2009. In particular, the January 2010 DWS, which captures job loss during the 2007-2009 period, provides a window through which to examine the experience of job losers in the Great Recession and to compare their experience to that of earlier job losers. These data show a record high rate of job loss, with almost one in six workers reporting having lost a job in the 2007-2009 period. The consequences of job loss are also very serious during this period with very low rates of reemployment, difficulty finding full-time employment, and substantial earnings losses.

JEL Classification: J63, J64

Keywords: displacement, job loss, unemployment

Corresponding author:

Henry S. Farber

Industrial Relations Section

Firestone Library

Princeton University

Princeton, NJ 08544

USA

E-mail: farber@princeton.edu

\footnotetext{
* This paper was prepared for a conference, "Unexpected Life-cycle Events and Economic Security: the Roles of Job Loss, Disability, and Changing Family Structure," held at the Federal Reserve Bank of San Francisco, May 20, 2011.
} 


\section{Introduction}

The Great Recession from December 2007 to June 2009 is associated with a dramatic weakening of the labor market from which it is now only slowly recovering. The unemployment remains stubbornly high, and durations of unemployment are unprecedentedly long. In this study I use the Displaced Workers Surveys (DWS), administered every two years from 19842010 as a supplement to the Current Population Survey (CPS), to examine the experience of job losers in the Great Recession and to compare their experience to that of earlier job losers, both in and out of recessions. The January 2010 DWS is of particular interest since it covers job loss during the period of the Great Recession (2007-2009). ${ }^{1}$

An important concern in the aftermath of the Great Recession is the high unemployment rate, which remained at 9.6 percent in the fourth quarter of 2010, more than one full year after the "official" end of the recession in June 2009. ${ }^{2}$ Figure 1 contains a plot of the quarterly seasonally adjusted civilian unemployment rate from 1978 through 2010. ${ }^{3}$ There has been substantial variation in labor market conditions over the period covered by the DWS (1981-2009). The early 1980s saw a sharp increase the unemployment rate to more than 10 percent during the July 1981 - November 1982 recession. This increase was followed by a long decline in during the remainder of the 1980s. The unemployment rate then increased to almost 8 percent in 1992 before beginning a long decline to about 4 percent in 2000 . After the comparatively mild recession in 2001 with a 6 percent unemployment rate, the unemployment rate again declined to about 4.5 percent in 2007 before increasing sharply to about 10 percent by 2010. Since that time the unemployment rate has fallen slowly.

A related concern are the unprecedentedly long durations of unemployment. This is illustrated in figure 2, which shows both the mean and median seasonally adjusted duration of unemployment for spells in progress, quarterly from 1978-2010. This figure clearly shows the

${ }^{1}$ Examples of earlier work using the DWS includes Farber (1993, 1997, 1998, 2005), Podgursky and Swaim (1987), Kletzer (1989), Topel (1990), Gardner (1995), Neal (1995), Esposito and Fisher (1997), and Hipple (1999). See Fallick (1996) and Farber (2004) for reviews of the earlier literature.

${ }^{2}$ This is the NBER dating of the recession. See the url at NBER (2010) for more an entry to a description of the NBER business cycle dating procedure. The labor market historically lags the NBER dates, which are based largely on GDP growth. For example, the unemployment rate in the recent period reported by the U.S. Bureau of Labor Statistics peaked in October 2009 while the NBER dated the end of the recession in June 2009.

3 These unemployment rates are based on my own calculations using the individual level CPS data available for this period. I weight by the CPS final sampling weights. In order to seasonally adjust a series $Y_{t}$ with overall mean $\bar{Y}$, I regress $Y_{t}$ on a complete set of seasonal dummy variables and calculate the residuals, $e_{t}$. I then compute the seasonally adjusted series as $Y_{t}^{s a}=\bar{Y}+e_{t}$. 


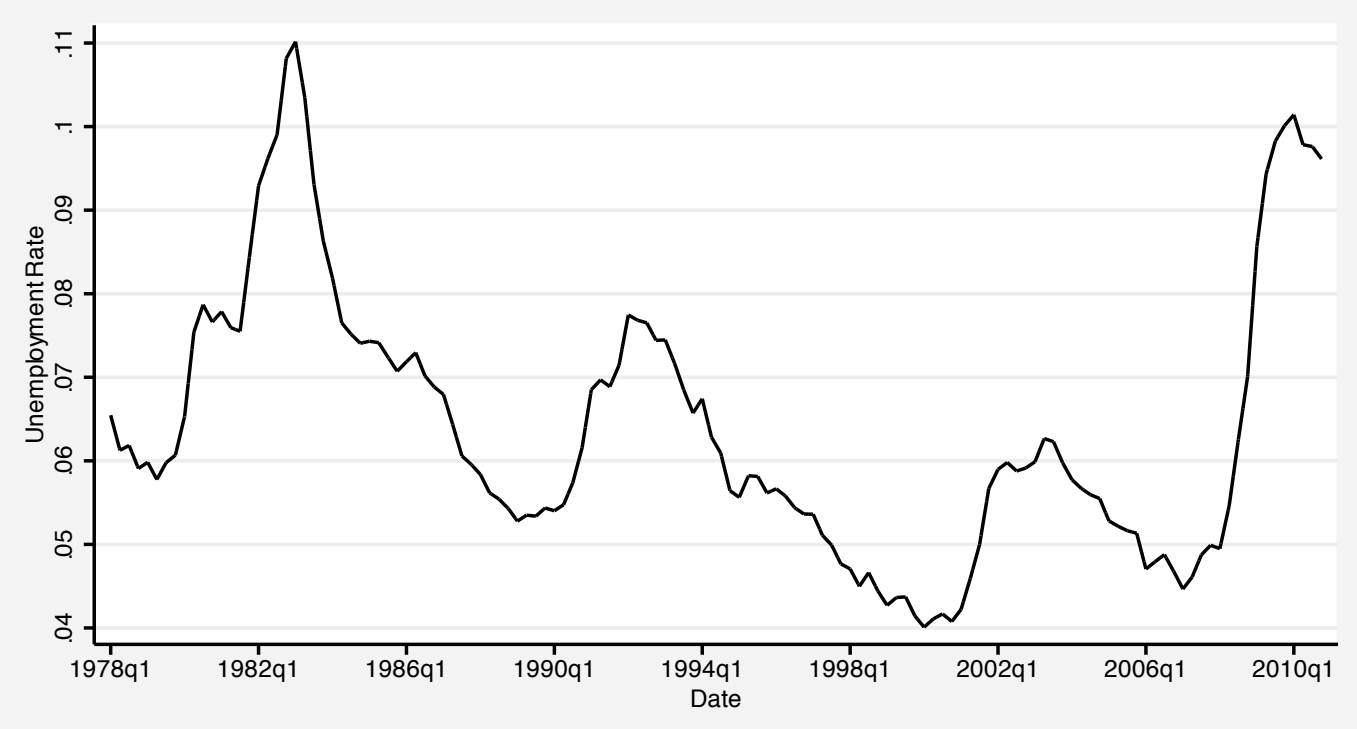

Figure 1: Civilian Unemployment Rate, seasonally adjusted

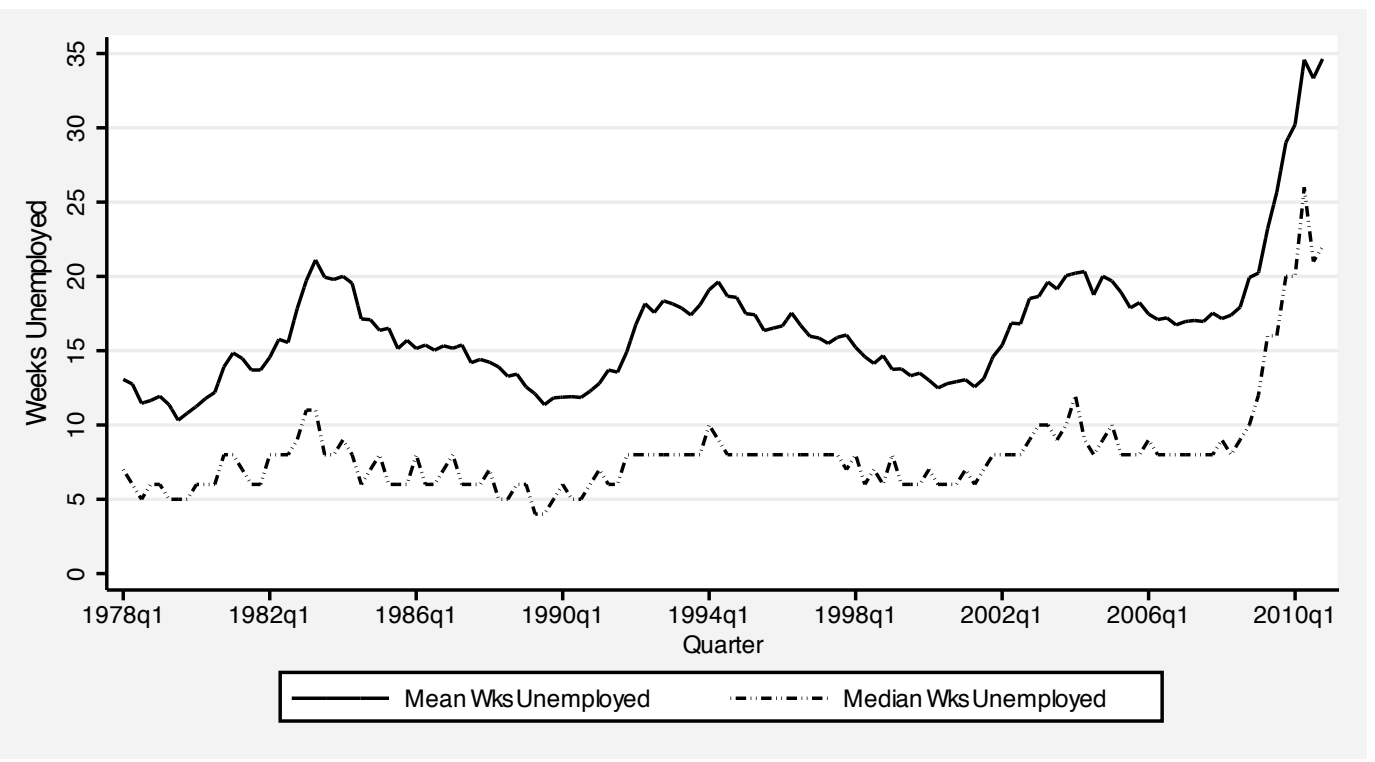

Figure 2: Duration of Unemployment, seasonally adjusted

counter-cyclical nature of unemployment duration. The mean unemployment rate reached about 20 weeks in the three earlier recessions show but rose to 35 weeks in the Great Recession. The median showed a similar pattern, reaching about 10 weeks in earlier recession but increasing to 35 weeks in the most recent recession.

It is clear that the dynamics of unemployment in the Great Recession are fundamentally different from unemployment dynamics in earlier recessions. I turn now to analysis of the 
experience of displaced workers in order to shed more light on how this recession has differed from earlier recessions with regard both to the incidence and costs of job loss.

I examine two sets of outcomes for displaced workers. The first set concerns post jobloss employment and unemployment experience These include rates of employment, unemployment and non-participation. I also examine durations of unemployment subsequent to job loss. The second set of outcomes concerns hours and earnings among reemployed job losers. I examine the full-time/part-time status of reemployed job losers at the DWS survey date. I also examine the change in weekly earnings for displaced workers between the predisplacement job and the job held at the DWS survey date. Because earnings of displaced workers likely would have changed had the workers not been displaced, I also use a control group of workers from the outgoing rotation groups of the CPS to compute the change in earnings over the same period covered by each DWS for workers who were not displaced. This allows me to break the earnings loss into two components: 1) the difference between the earnings received by job losers on their post-displacement job and the earnings they received prior to displacement and 2) foregone earnings growth measured by the earnings growth received by the control group of non-displaced workers. I then use these changes to compute difference-in-difference (DID) estimates of the effect of displacement on earnings of reemployed workers.

\section{The Displaced Workers Survey: Data Issues}

I analyze data on 1,058,244 individuals between the ages of twenty and sixty-four from the DWS conducted as part of the January or February CPS in even years from 1984 through 2010. The survey is meant to capture worker terminations as the result of business decisions of the employer (e.g., a plant closing, a layoff, the abolition of a job) unrelated to the performance or choices of the particular employee. As such, it is not meant to capture voluntary job changes (quits) or termination "for cause." While the precise question asked varied somewhat over time, in January 2010 respondents were asked:

"During the last 3 calendar years, that is, January 2007 through December 2009, did (name/you) lose a job or leave one because: (your/his/her) plant or company closed or moved, (your/his/her) position or shift was abolished, insufficient work or another similar reason?"

There are three important issues of measurement and interpretation that arise when comparing job loss rates calculated using the DWS over time. 
1. The DWS asks only about a single involuntary job loss. The survey does not capture multiple job losses by the same worker. Thus, the job loss rate I calculate is the fraction of workers who lost at least one job not "for cause" in the relevant period. Note that this job loss rate is not the rate of destruction of worker-employer matches (not least because it does not capture quits).

2. The DWS from 1984-1992 asked about job separations in the previous five years while the later DWS asked about job separation in the previous three years. The measure of job loss that I use is adjusted to account for this change in the recall period so that all rates are reported on a three-year basis. This adjustment is detailed in Farber (1997).

3. The basic wording of key questions changed since the inception of the DWS in 1984. This may have affected whether survey respondents would report a job separation in a particular circumstance as an involuntary separation in one survey but would not report a separation in the same circumstance as involuntary in another year. In Farber (2004), I used additional data from debriefing questions asked of a fraction of DWS respondents in 1996, 1998, and 2000 to investigate how changes in the wording of the key question may have affected the likelihood that a worker reported a particular separation as an involuntary job change. I use the results of that analysis to calculate re-weighted job loss rates that I present in this study.

I count as job losers workers who reported a job loss in the three calendar years prior to the survey. Based on these data, I calculate the rate of job loss as the ratio of the number of reported job losers divided by the number of workers who were either employed at the survey date or reported a job loss but were not employed at the survey date. I then adjust these job loss rates as described in Farber (1998) and Farber (2004) to account for the change in the recall period from five years to three years in 1994 and changes in the wording of the key job loss question. ${ }^{4}$

Another design change in the DWS since 1994 complicates the analysis of the consequences of job loss. Since 1994, the follow-up questions designed to gather information on the characteristics of the lost job and experience since job loss were asked only of job losers whose reported reason for the job loss was one of three reasons: slack work, plant closing, or position/shift abolished. I term these the "big three" reasons. Workers who lost jobs due to

\footnotetext{
${ }^{4}$ Job losers are asked to report the reason for their job loss. One allowable response is "other." The adjustment for changes in the wording of the key job loss question discounts job loss rates for "other" reasons by $37.4 \%$ for the 1984-1992 DWS and by $74.8 \%$ for the 1994 and later DWSs. See Farber (1998) for details.
} 
the ending of a temporary job, the ending of a self-employment situation, or "other" reasons were not asked the follow-up questions. In order to maintain comparability across years my analysis of post-job-loss experience, regardless of year, uses only workers who lost jobs for the "big three" reasons. Additionally, in order to have a consistent sample over time, I do not use information on job losers in the 1984-1992 DWS whose reported job loss was more than three years prior to the interview date.

\section{The Rate of Job Loss}

Information on rates of job loss is presented most accessibly in graphical form, and the discussion here is organized around a series of figures. ${ }^{5}$

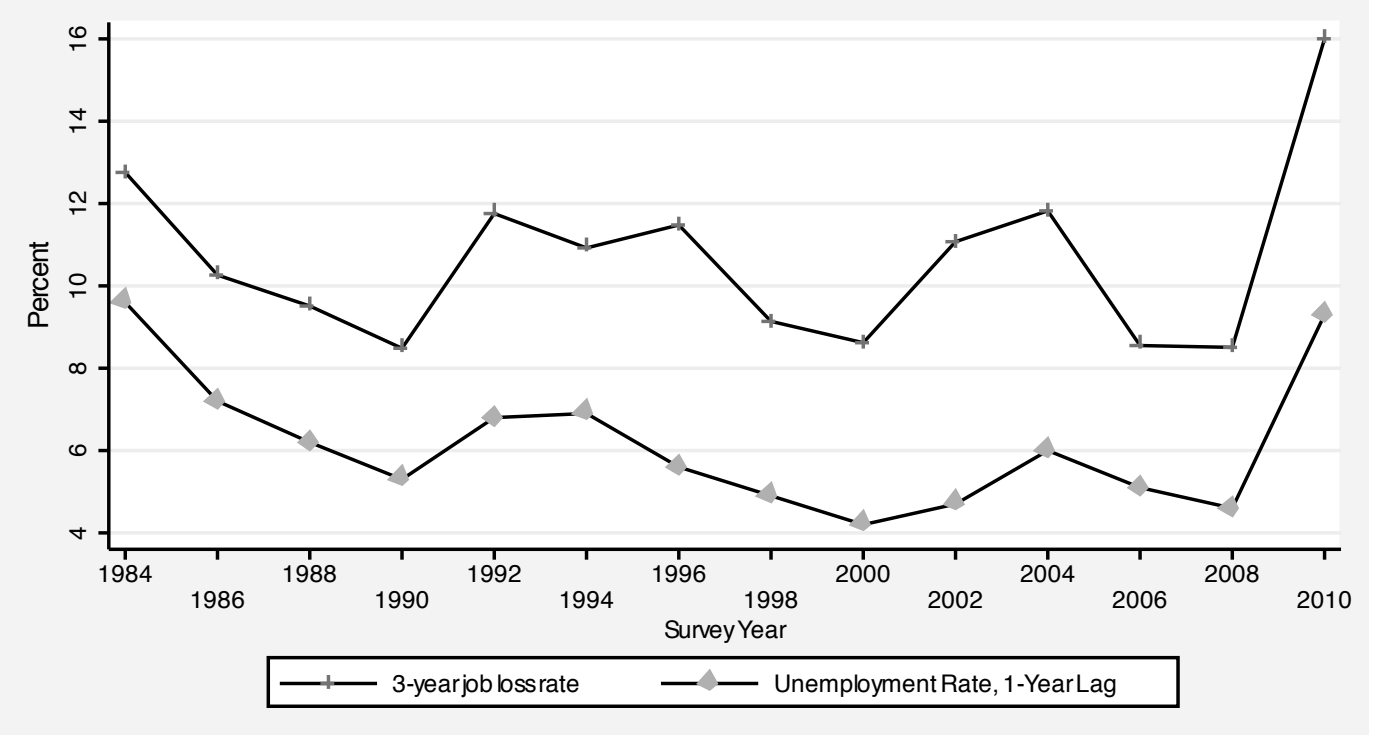

Figure 3: Unemployment and Job Loss Rates, by Survey Year

Figure 3 contains plots of adjusted three-year job loss rates computed from each of the ten DWSs from 1984-2010 along with the civilian unemployment rate for the year preceding each survey. The cyclical behavior of job loss is apparent, with job-loss rates clearly positively correlated with the unemployment rate $(\rho=0.80) .{ }^{6}$ Both unemployment and job-loss rates

${ }^{5}$ All counts are weighted using the CPS sampling weights. The numerical values underlying all figures in this study (other than figures 1 and 2) are contained in Appendix II.

${ }^{6}$ Another possibility would be to use the average unemployment rate for the three years preceding each survey. However, reported rates of job loss are always higher in the year immediately preceding the survey 


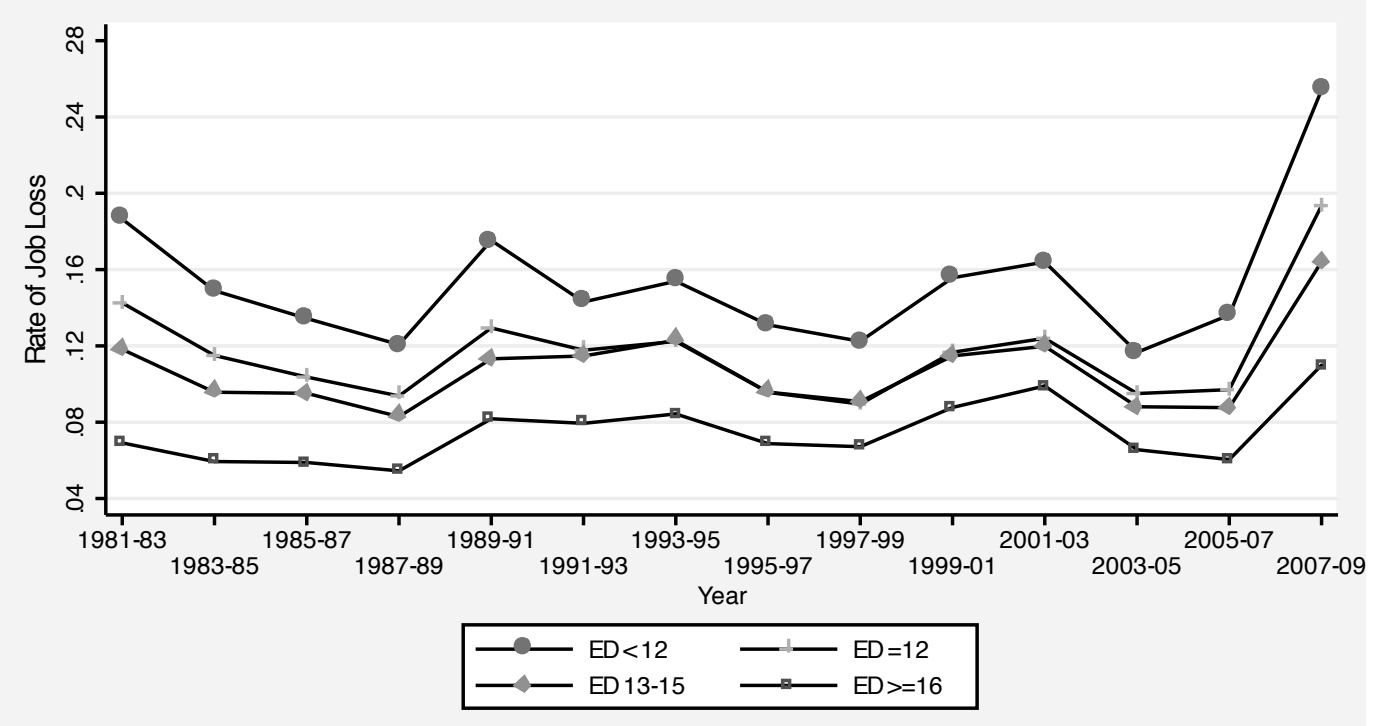

Figure 4: Three-Year Job Loss Rate by Education, 1981-2003.

were very high in the two most serious recessionary periods (1981-83 and 2007-09, the 1984 and 2010 survey years respectively). While the unemployment rates were comparable in 1983 and 2009 (9.6 percent vs. 9.3 percent), the job loss rate was much higher in the 2007-2009 period than in the 1981-83 period (16.0 percent vs. 12.8 percent). This suggests that the Great Recession was associated with a much higher job loss rate than the norm, which makes it of particular interest to study the consequences of job loss in the most recent period.

Figure 4 contains three-year rates of job loss by year for each of four education categories. Not surprisingly, job loss rates are dramatically higher for less educated workers than for more educated workers. For example, the job loss rate for workers with twelve years of education was 9.4 percent in 1997-99 (the lowest in the sample period) compared with 14.3 percent in 1981-83 and 19.4 percent in 2007-09. In contrast, the job loss rate for workers with at least sixteen years of education was 5.4 percent in 1987-89 compared with 6.9 percent in 1981-83 and 11.0 percent in 2007-2009. Clearly, there is a strong cyclical pattern in job loss rates for less educated workers. Among more educated workers, there is a more complicated pattern. Consider workers with at least 16 years of education. Early on, there was little

relative to the rates of job loss two and three years preceding the survey. This may be the result of recall bias noted by Topel (1990). Empirically, the correlation of the rate of job loss with the unemployment rate in the year preceding the survey $(\rho=0.80)$ is much higher than the correlation of the rate of job loss with the average unemployment rate in the three years preceding the survey $(\rho=0.42)$. 


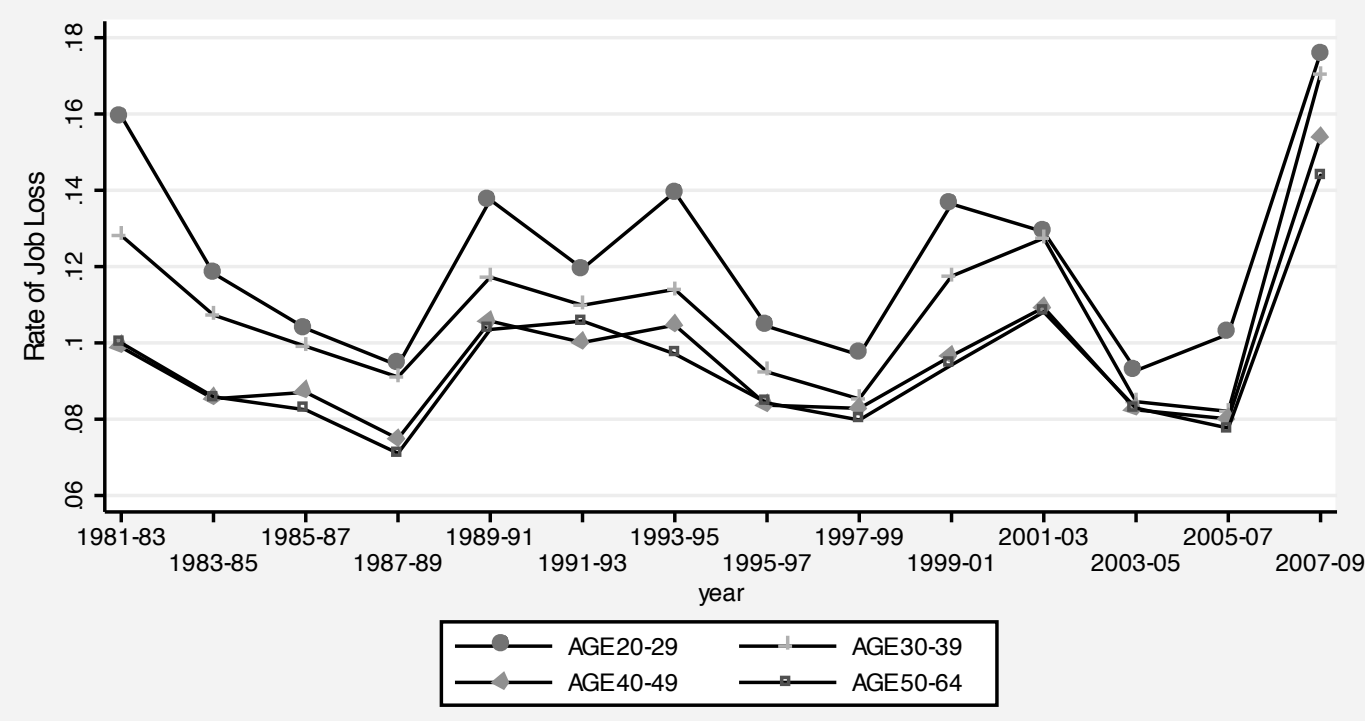

Figure 5: Three-Year Job Loss Rate by Age, 1981-2003.

cyclical movement of job loss rates for these workers. Job loss rates fell only slightly in the recovery from the early 1980s recession. However, the rate of job loss increased substantially in the 1989-91 period, did not fall much during the subsequent recovery, increased again from 1997-2003, before falling through 2007. In the most recent period (2007-09), the job loss rate of college graduates increased sharply (from 6 percent in 2005-07 to 11 percent in 2007-09). While the 2007-09 rate of job loss for college graduates is substantially below the rate for workers with more education, it is at a historically high level. The conclusion is that more educated workers are less vulnerable to job loss, but even their vulnerability has increased over time.

Figure 5 contains three-year job loss rates by year for four age groups covering the range from 20-64. Job loss rates are highest for the youngest workers (20-29) and generally show the standard cyclical pattern. The job loss rates of the oldest two group, ages 40-49 and 50-64, are very similar. There has been some convergence over time in rates of job loss by age, with the rates for older workers increasing relative to those for younger workers. 


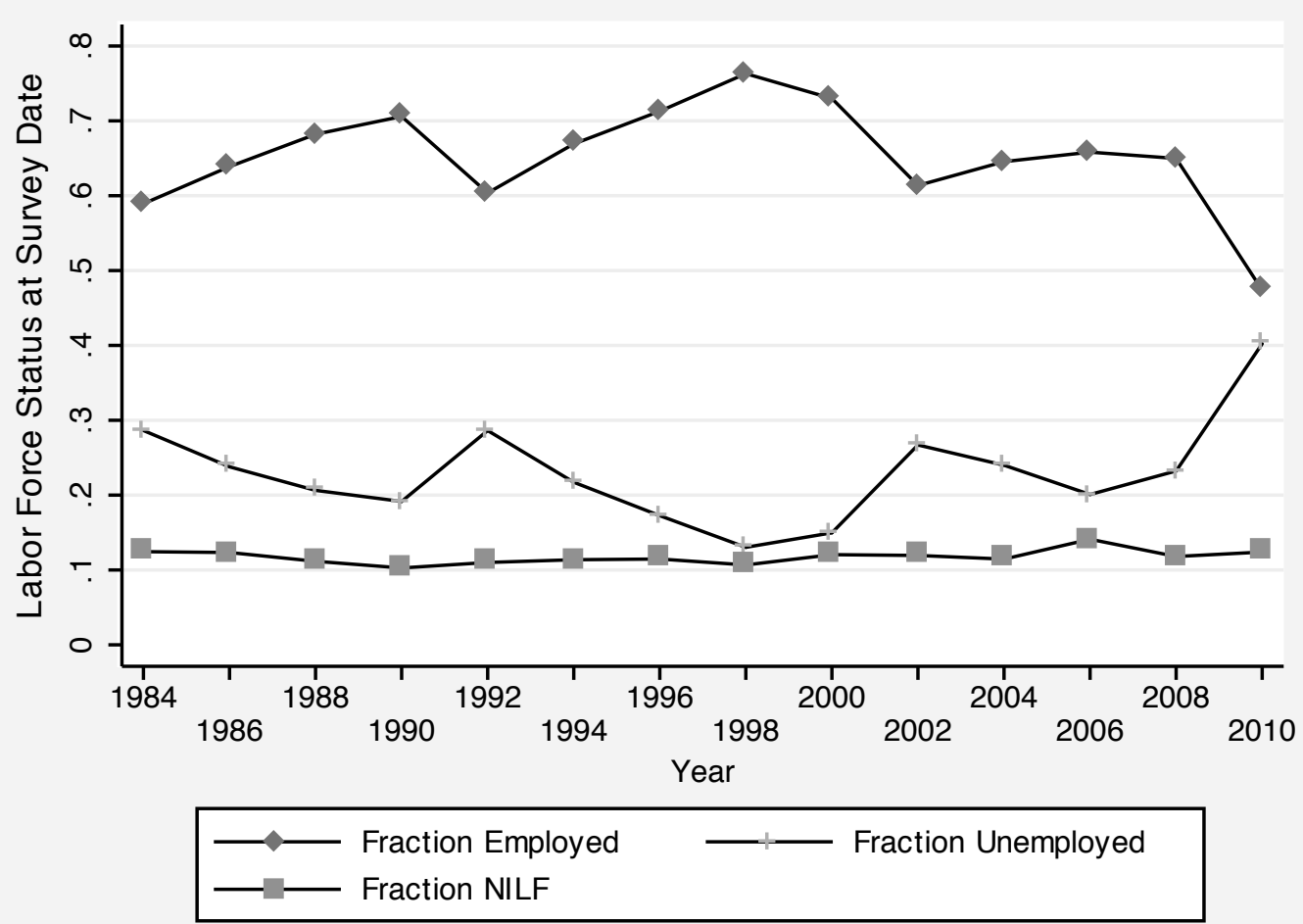

Figure 6: Survey Date Labor Force Status of Job Losers

\section{Consequences of Job Loss: Employment and Unemployment}

\subsection{Post-Displacement (Survey Date) Labor Force Status}

In this section, I examine how the distribution of survey-date labor force status of workers has varied over time and with other factors including sex, education, and age. Figure 6 contains plots of the fraction employed, unemployed, and not in the labor force at the DWS survey dates for job losers in each of the DWSs. It is clear from this figure that the postdisplacement employment rate is pro-cyclical, with relatively low rates surveys covering the slack labor markets 1984, 1992, 2002, and 2010. The most striking feature of this plot is that the post-displacement employment rate substantially lower, less than 50 percent, in the 2010 survey (covering job loss in the 2007-2009 period of the Great Recession) than in any earlier period.

Not surprisingly, the survey-date unemployment rate among job losers moves countercyclically, with peak unemployment rates at the 1984, 1992, 2002, and 2010 survey dates. The most striking feature of the unemployment plot is that the post-displacement unemployment 

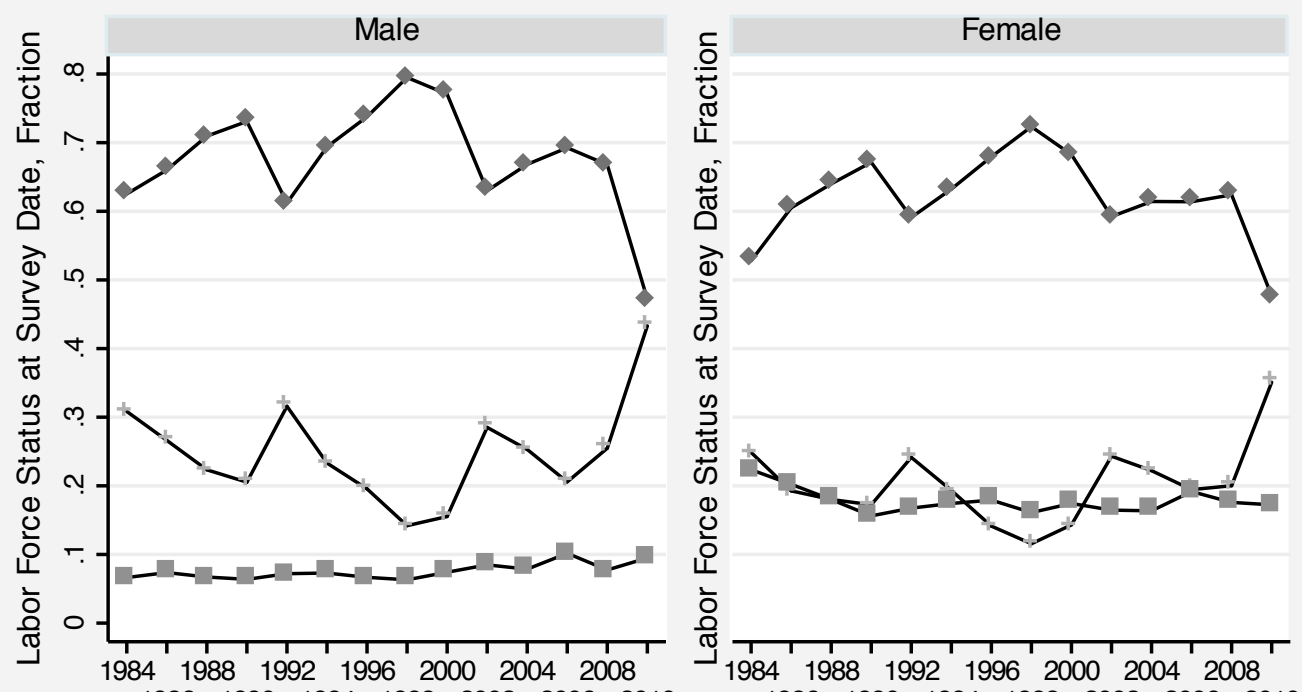

1986199019941998200220062010

1986199019941998200220062010

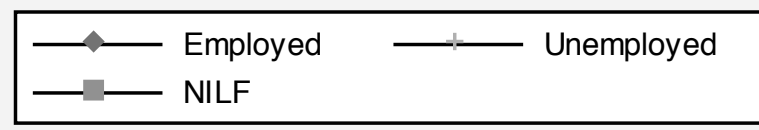

GraphsbySex

Figure 7: Survey Date Labor Force Status of Job Losers, by Sex

rate is substantially higher lower, about 40 percent, in the 2010 survey than in any earlier period.

The survey-date fraction of job losers not in the labor force is remarkably constant across all years, at about 10 percent. There is no evidence that job losers are disproportionately discouraged in recessions, including the most recent recession, leading to withdrawal from the labor force.

It is clear from figure 6 that the re-employment experience of job losers is substantially worse for those who lost jobs in the Great Recession than in any earlier period in the last thirty years.

\subsubsection{Post-Displacement Labor Force Status by Sex}

Figure 7 contains plots of the distribution of survey-date labor force status by sex. The male and female plots show the same cyclical patterns, including the aggregate finding that employment rats are lowest and unemployment rates highest in the most recent period. One contrast is that female job losers have weaker attachment to the labor force than do males. 
Women have lower post-displacement unemployment rates and substantially higher fractions not in the labor force. It is worth noting that these differences by sex are among both men and women who were working and lost a job so that this does not simply reflect the fact that some women are consistently out of the labor force. ${ }^{7}$ In January 2010 men and women had comparable post-displacement employment rates of 47 percent and 48 percent, respectively. Fully 43 percent of Male job losers were unemployed in January 2010 compared with "only" 35 percent of female job losers. The difference results from the fact that 10 percent of male job losers had withdrawn from the labor force, compared with 17 percent of female job losers.

\subsubsection{Post-Displacement Labor Force Status by Education}

Another important dimension along which there are differences is education. Figure 8 contains plots of survey-date employment probabilities for displaced workers by year broken down by education. Not surprisingly, the likelihood of post-displacement employment rises with education while there is a negative relationship between post-displacement unemployment and education.

The usual cyclical pattern of both the employment and unemployment fractions exists at all education levels, and the Great Recession has been hard on workers in all education groups. Only 41 percent of job losers with a high school education were employed in January 2010. This compares with a 59 percent post-job loss employment rate for high school graduates in 1984, the survey year covering the 1982 recession. The post-job-loss employment rate for college graduates was 59 percent in January 2010 compared with a 78 percent employment rate for college graduates in 1984. The fraction unemployed follows an analogous pattern.

\subsubsection{Post-Displacement Labor Force Status by Age}

There are also strong differences in post-displacement labor force status by age. Figure 9 contains plots of survey-date employment probabilities for displaced workers by year broken down by age. As with sex and education, the usual cyclical pattern of both the employment and unemployment fractions exists at all age levels. Not surprisingly, prime-age job losers (25-54 years of age) have the strongest attachment to the labor force. They have the highest fraction employed and the lowest fraction out of the labor force. Interestingly, older job

\footnotetext{
7 The sex difference may reflect the fact that some women have a richer set of alternative activities on which to spend time, such as child bearing. It may be that the timing of job loss among females, with its exogenous loss of specific capital, affects the timing of fertility decisions.
} 

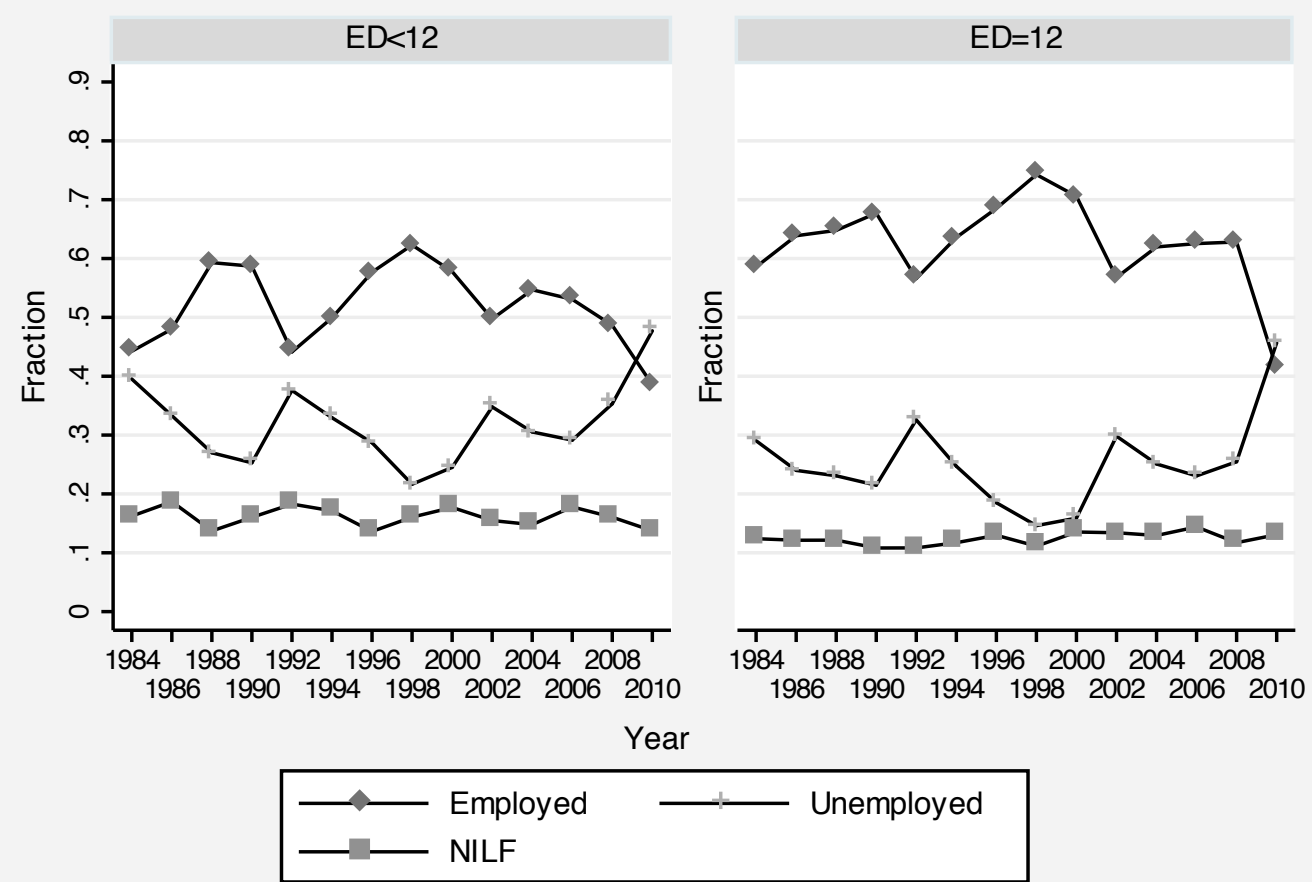

Graphsbyeducationalcategories

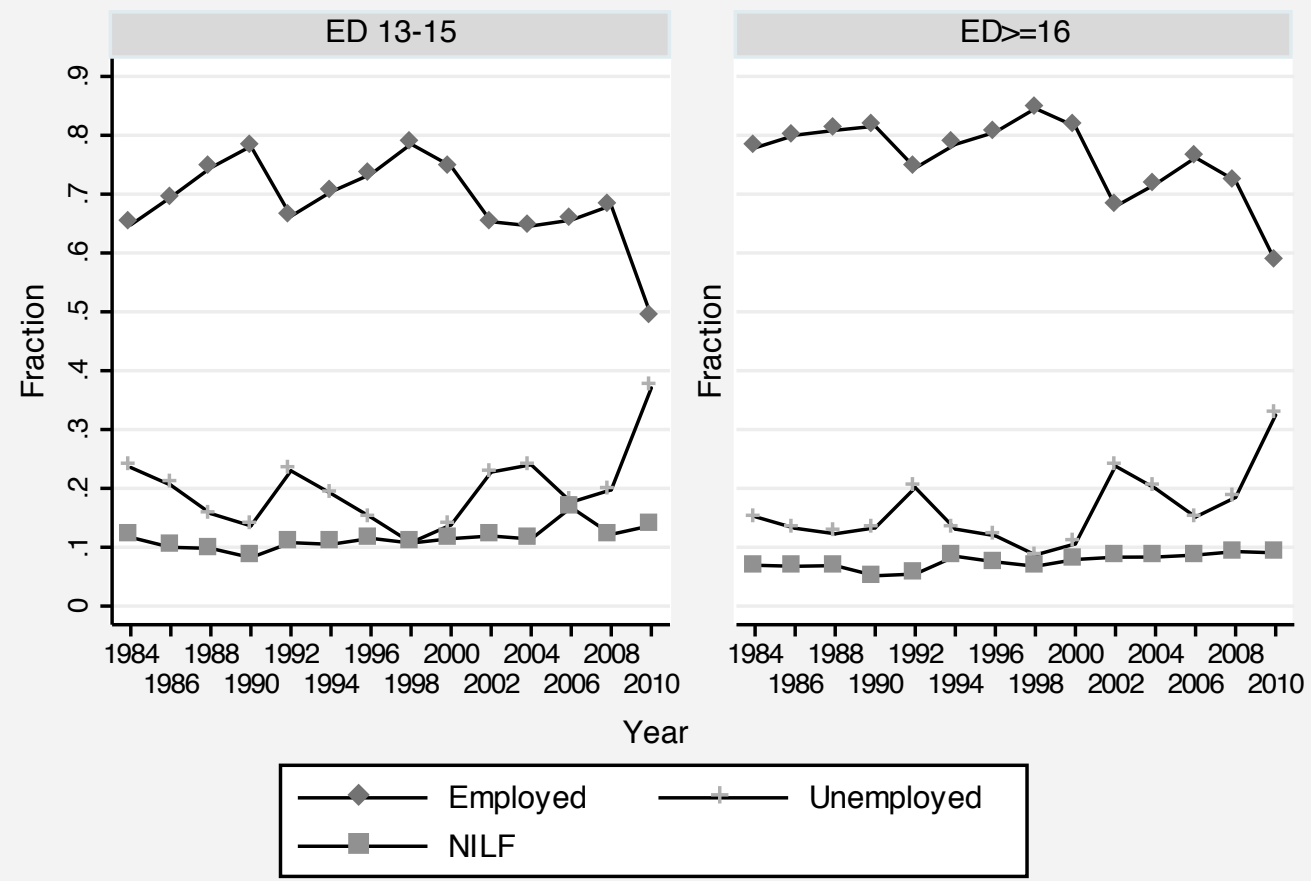

Graphsbyeducationalcategories

Figure 8: Survey Date Labor Force Status of Job Losers, by Education 

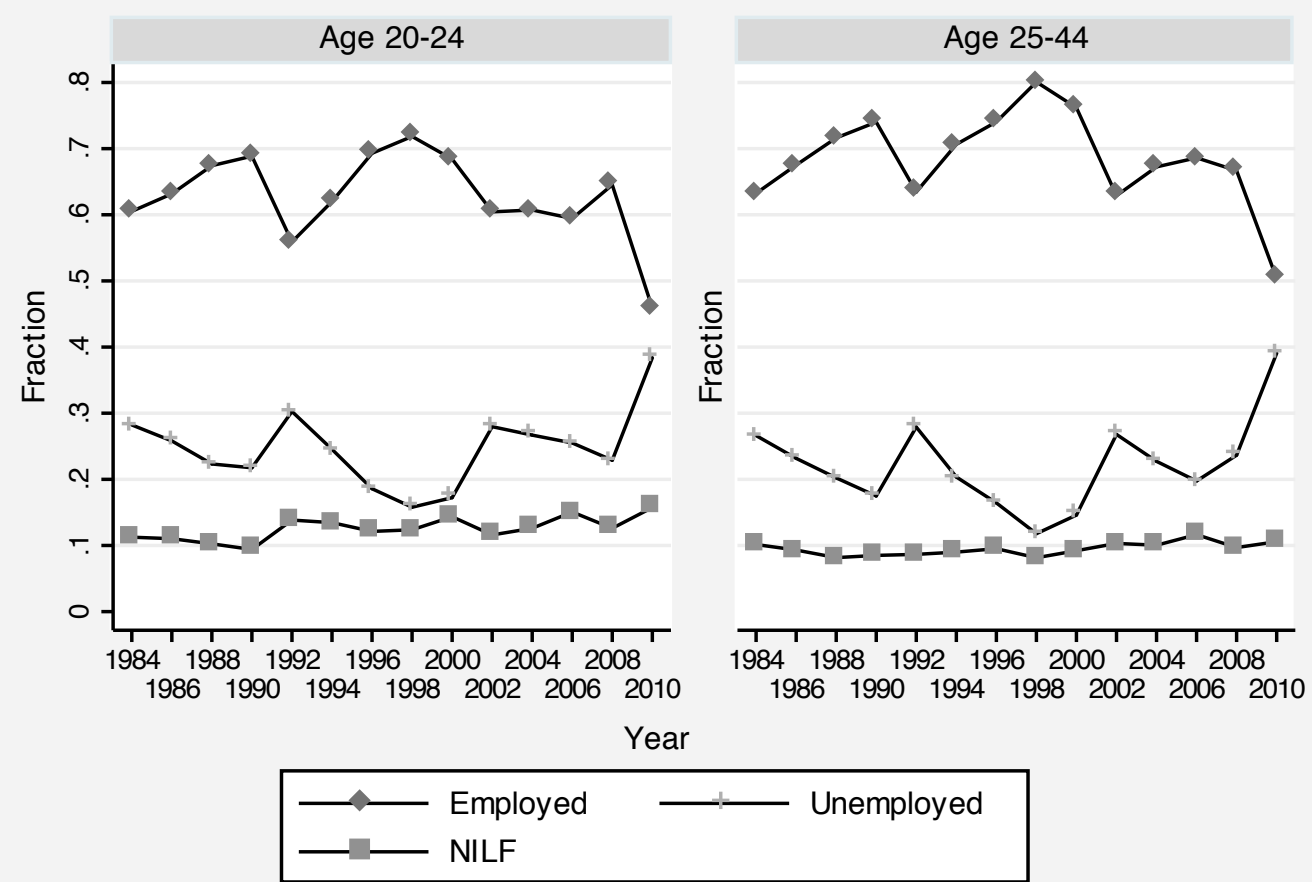

Graphsby Age Category

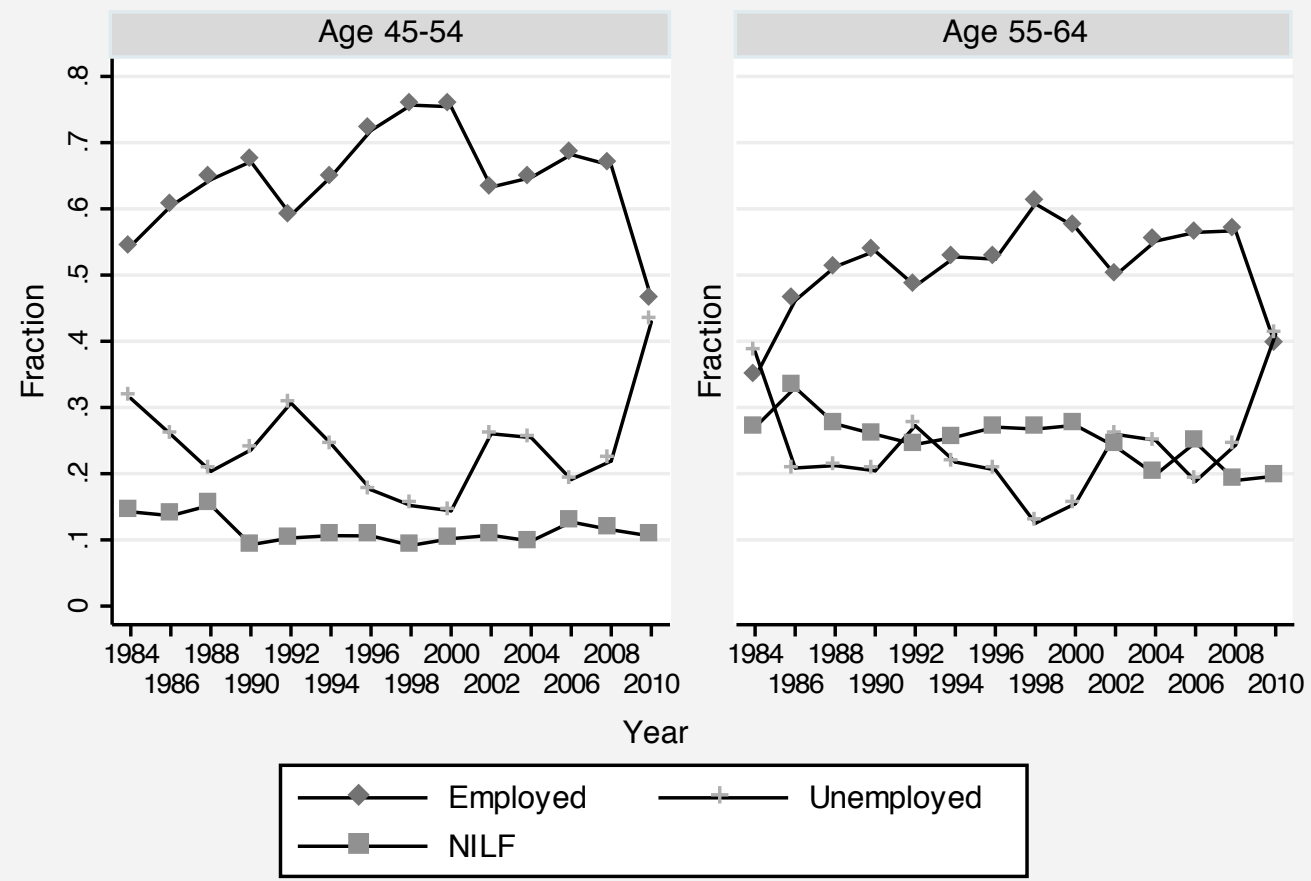

Graphsby Age Category

Figure 9: Survey Date Labor Force Status of Job Losers, by Age 
losers (55-64 years of age) used to be substantially more likely than younger job losers to be out of the labor force, but this difference has declined in recent years.

Since older job losers have, on average, more seniority on the lost job, it is likely that they lose more specific capital on average as a result of job loss then do younger workers. The result is that the gap between earnings on the lost job and likely reemployment earnings of older displaced workers will be relatively large. In this situation it would not be surprising that a substantial fraction of older displaced workers would decide to retire and report that they are not in the labor force subsequent to job loss.

All age groups have suffered in the Great Recession. Even job losers 45-54 years of age have an employment rate of about 45 percent, while those aged 55-64 have an employment rate of 40 percent. The post-job-loss fraction unemployed increased sharply for in all age groups. Interestingly, it does not appear that even the oldest job losers in the Great Recession have an increased rate of withdrawal from the labor force. There is some increase in the fraction not in the labor force for the youngest job losers, probably reflecting re-enrollment in school.

\subsection{Duration of Unemployment/Non-Employment}

The core question on unemployment duration in the DWS is "After that job [referring to the lost job] ended, how many weeks went by before you started working again at another job?" However, the DWS is not well designed to study the duration of unemployment following job loss. This is for several reasons.

- The core question is asked of all job losers only between 1988 and 1992.

- Between 1994 and 2010, the core question is asked only of job losers who found another job.

- The unemployment duration question asked in 1984 and 1986 refers to total time spent unemployed between the job loss and the survey date rather than time spent unemployed until a new job was found.

- The data are miscoded (largely missing) in 1994.

The result is that consistent data are available from the 1988-92 and 1996-2010 DWS.

The key limitation with these data is that, other than in 1984 and 1986, there is no information on unemployment duration for those job losers who did not find a new job. 


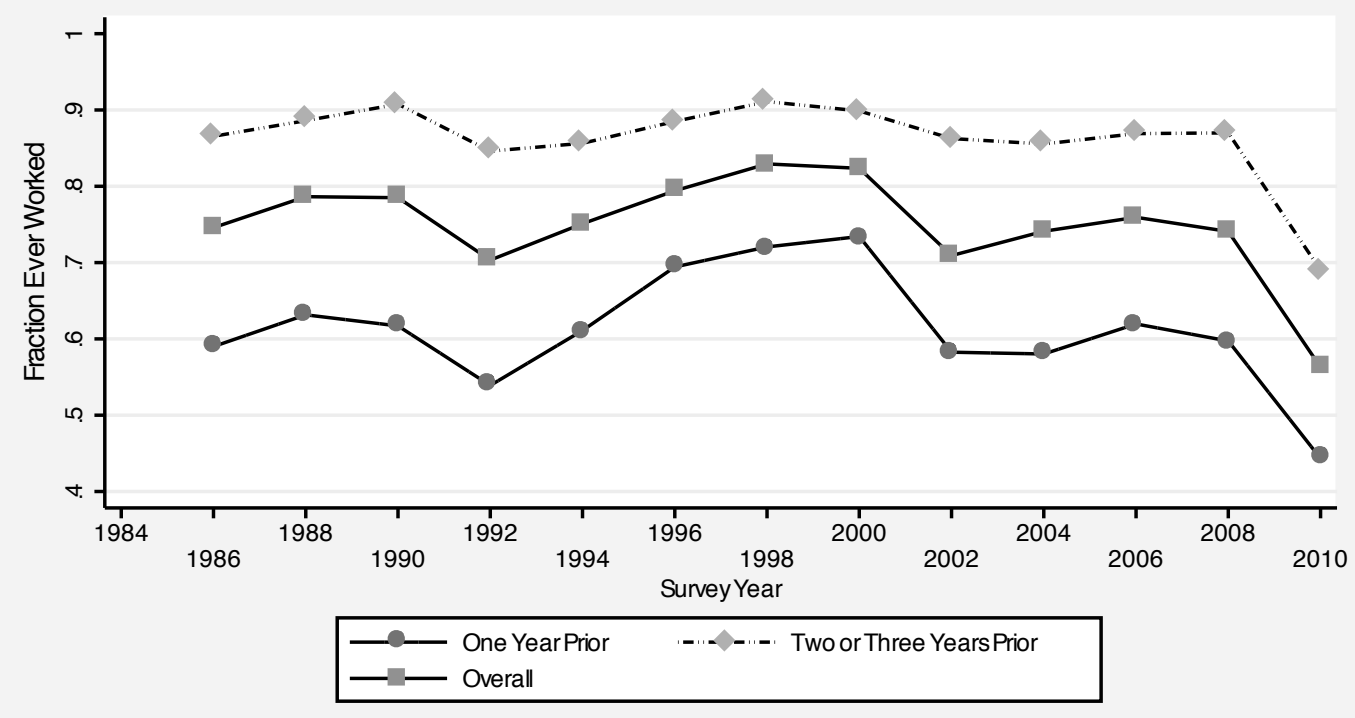

Figure 10: Fraction Ever Employed Subsequent to Job Loss, by Time Since Job Loss.

Still, it is of interest to investigate these durations, and I start by presenting information on the fraction of job losers who find another job by the survey date.

\subsubsection{Ever Employed Subsequent to Job Loss?}

A complicating factor in this analysis is that the date of job loss is not known beyond recorded information on the calendar year of the job loss. Since the DWS is early in the year (January or February), a job reported lost, for example, in the calendar year prior to the survey was actually lost between 1 and 14 months prior to the survey. Since the likelihood of finding a new job is increasing in the time since job loss, I present information on reemployment probabilities separately by years since job loss (survey year minus reported year of job loss). Figure 10 contains a plot of the fraction ever employed among job losers by the number of calendar years prior to the survey in which the job was lost. ${ }^{8}$ It is clear that job finding rates are lower for jobs lost in the year prior to the survey date than in jobs lost two or three years prior to the survey date. ${ }^{9}$ This is likely the result of the fact that earlier job losers have had more time to search for a new job and are more likely to have exhausted their

${ }^{8}$ The 1984 DWS did not contain information on whether a job loser was ever employed subsequent to displacement, so this analysis is limited to the 1986-2010 period.

${ }^{9}$ There is not much difference in reemployment rates between jobs lost two calendar years prior to the survey date and jobs lost three years prior to the survey date, and I combine these categories in the figure. 


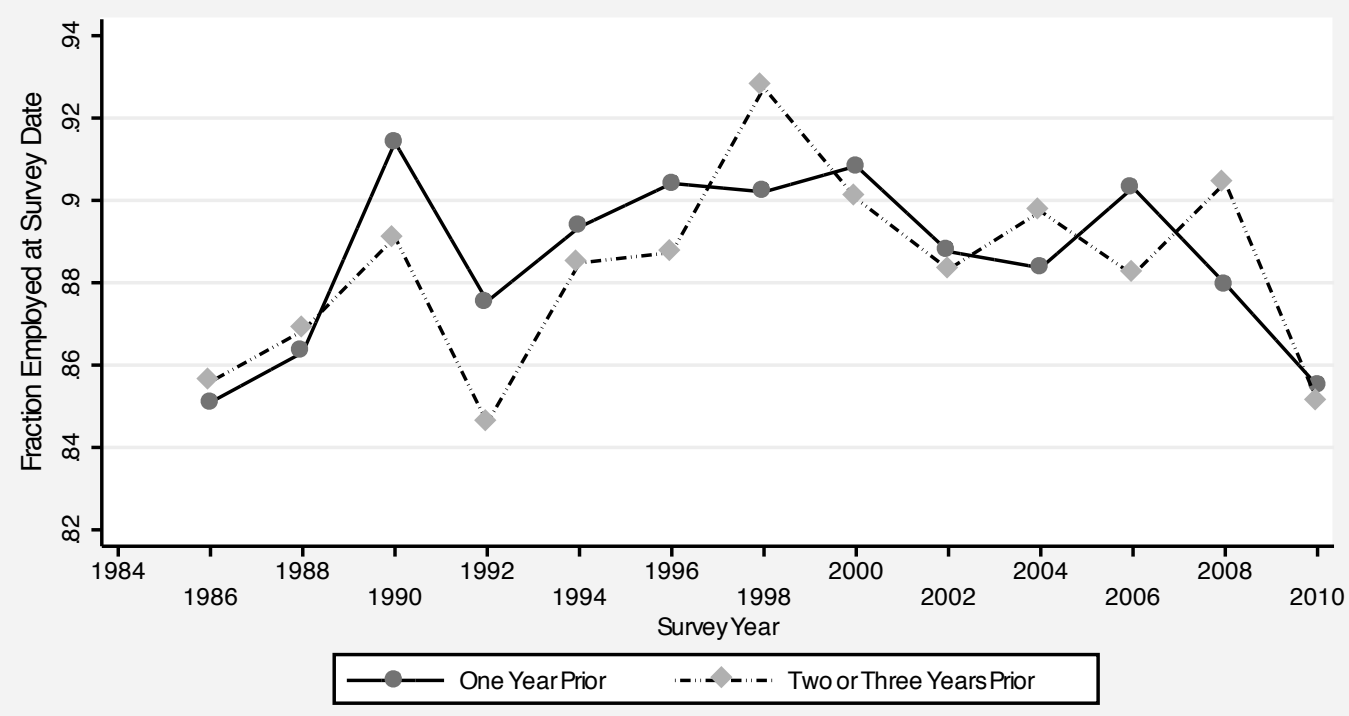

Figure 11: Fraction Employed at Survey Date, Conditional on Holding at Least One PostDisplacement Job. By Time Since Job Loss.

unemployment benefits. Indeed, job losers reporting a loss in the calendar year immediately prior to the survey date could have lost their job as recently as one month earlier.

Not surprisingly, there is a counter-cyclical pattern to the likelihood of finding a job subsequent to displacement. In the great recession, only 56 percent of job losers (regardless of time since job loss) had found a job by the DWS survey date. This is the lowest job finding rate in the period covered by the data (1986-2010).

In order to relate this analysis of the likelihood of ever finding a job after displacement to the earlier analysis (figure 6) of employment status at the DWS survey date subsequent to job loss, figure 11 contains a plot of the fraction of job losers who were employed at the survey date conditional on holding at least one job since displacement. This probability varies over a narrow range between 0.84 and 0.93 , but it shows both a distinct counter-cyclical pattern as well as an increasing trend through 2000 followed by a decline trend subsequently. A comparison of figures 6 and 10 shows that a substantially higher fraction of job losers report having found a job by the survey date than report being employed at the survey date. This is not surprising, but it highlights the fact that individuals who have lost a job may well lose another job subsequently. ${ }^{10}$ Post-job-loss reemployment experience was clearly worse in the

\footnotetext{
${ }^{10}$ Recall that the DWS records only a single job loss for an individual. The interviewer instructions ask the respondent, in the case of multiple job losses, to report the loss of the job held longest rather than the
} 


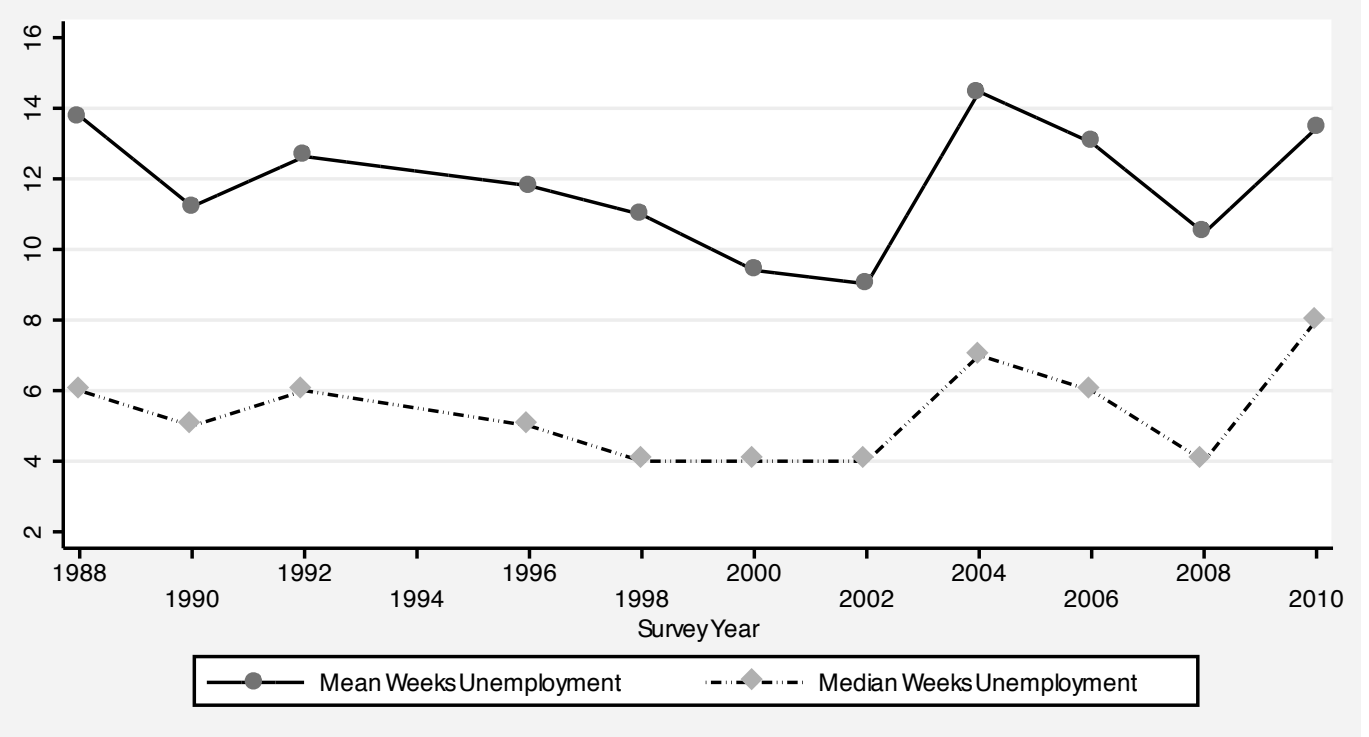

Figure 12: Weeks of Unemployment Before Finding New Job, Conditional on Holding at Least One Post-Displacement Job.

Great Recession than in any earlier period. The finding that 56 percent of job losers report having found a job by the 2010 DWS survey date and that only 47 percent job losers report being employed at the 2010 DWS survey date (compare figures 6 and 10), suggests that at least 16 percent (1-0.47/0.56) of reemployed job losers subsequently lost or left their new post-displacement job. ${ }^{11}$

\subsubsection{Duration of Unemployment among Reemployed Job Losers}

Figure 12 contains plots of the mean and median time unemployed (in weeks) until a job is found for those job losers who were successful in finding a job. Interestingly, the mean time to job finding was a week higher in 2004 than in 2010 (14.5 weeks vs. 13.4 weeks). Median time to job finding is highest in 2010 than in earlier years, though only one week higher than in 2004 ( 8 weeks vs. 7 weeks).

The contrast with reported durations of spells in progress among unemployed workers (figure 2) is striking. Mean unemployment duration for spells in progress in 2010 was almost

job held most recently. It is also the case that individuals can be not-employed as a result of a quit as well as the result of a job loss.

11 This is a lower bound because other reemployed job losers may have lost or left their job and subsequently found another new job. 
35 weeks, with a median of about 25 weeks. As noted above, the analogous figures for time to employment for reemployed job losers is a mean of 13.4 weeks and a median of 8 weeks. On the one hand, this is surprising because the time to employment for reemployed job losers is the length of a completed spell of unemployment, while the duration of unemployment reported in the CPS is for spells in progress (incomplete). On the other hand, the durations reported in the DWS are for completed spells and omit the spells still in progress. These spells omitted in the DWS are the longer spells so that the mean duration is biased downward as an estimate of the length of all spells. Additionally, there is the usual length-biased sampling problem when examining the duration of spells in progress at a point in time, as in the CPS so that the sample of spells reported in the CPS is biased toward longer spells. I conclude from this analysis and from the finding that only 56 percent job losers in the 2010 DWS report ever finding a job after displacement (figure 10) that those job losers in the Great Recession who were successful in finding a new job did not take an inordinately long time to find work. However, a much higher fraction of job losers have been unsuccessful in finding a job, and these workers have very long spells of unemployment.

\section{Consequences of Job Loss: Hours and Earnings}

\subsection{Post-Displacement Full-Time/Part-Time Status}

Many reemployed job losers are employed part time subsequent to job loss. Some of these workers lost part-time jobs but many had lost full-time jobs. In addition to having lower weekly earnings, it is well known that part-time workers have substantially lower hourly wage rates and less access to fringe benefits like health insurance and pensions than do full-time workers (Farber and Levy (2000)). The DWS collects information on part-time status (less than 35 hours per week) on the lost job, and it is straightforward to compute part-time status on post-displacement jobs from the standard CPS hours information. The analysis in this section focuses only on individuals employed at the survey date, and all part-time rates are computed based on this group of workers.

Figure 13 contains a plot of the fraction employed of employed job losers who are employed part-time at each survey date conditional on part-time status on the lost job. ${ }^{12}$ Not

\footnotetext{
12 Note that there is a problem of temporal comparability of the data on part-time employment at the survey date. The new survey instrument, first used in the 1994 CPS, asks a different battery of questions about hours of work on the current job, and this may have the effect of raising the fraction of workers reporting they are currently working part time (Polivka and Miller, 1998). The survey question regarding
} 


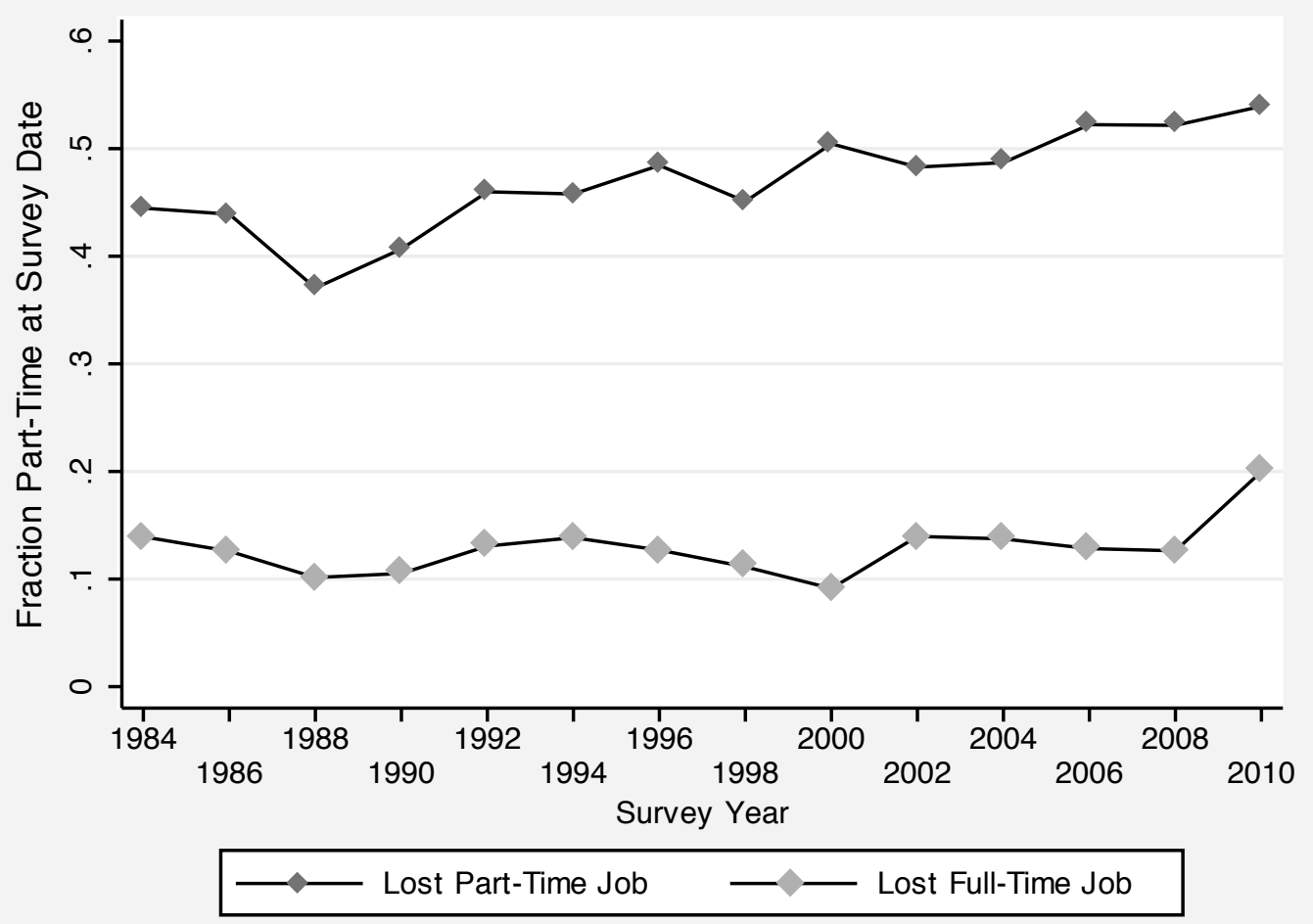

Figure 13: Fraction Part-Time at Survey Date, by Part-time Status on Lost Job

surprisingly, workers who lose part-time jobs are substantially more likely to be working on part-time jobs at the survey date. Many of these workers are part-time due to labor supply choices, and it is reasonable to expect that these workers would continue to choose to work part time. It is noteworthy, then, that on the order of 50 percent of part-time job losers are working full-time at the survey date, although this fraction has decreased substantially since the late 1980s. Among re-employed part-time job losers in the 2007-09 period, about 46 percent are working full-time in January 2010.

In terms of the cost of job loss, a more interesting group to study consists of those workers who lost full-time jobs. Between 10 and 15 percent of these job losers were working part-time at the survey dates from 1984-2008. The part-time rate among full-time job losers increased substantially to 20 percent in 2010 . Thus, even among the 50 percent of job losers who were re-employed, a substantial fraction of full-time job losers did not find full time employment.

More generally, there is a cyclical component to the ability of full-time job losers to find full-time employment. The post-displacement part-time rate among full-time job losers is

whether the lost job was part-time is unchanged in the 1994 and later DWSs. 


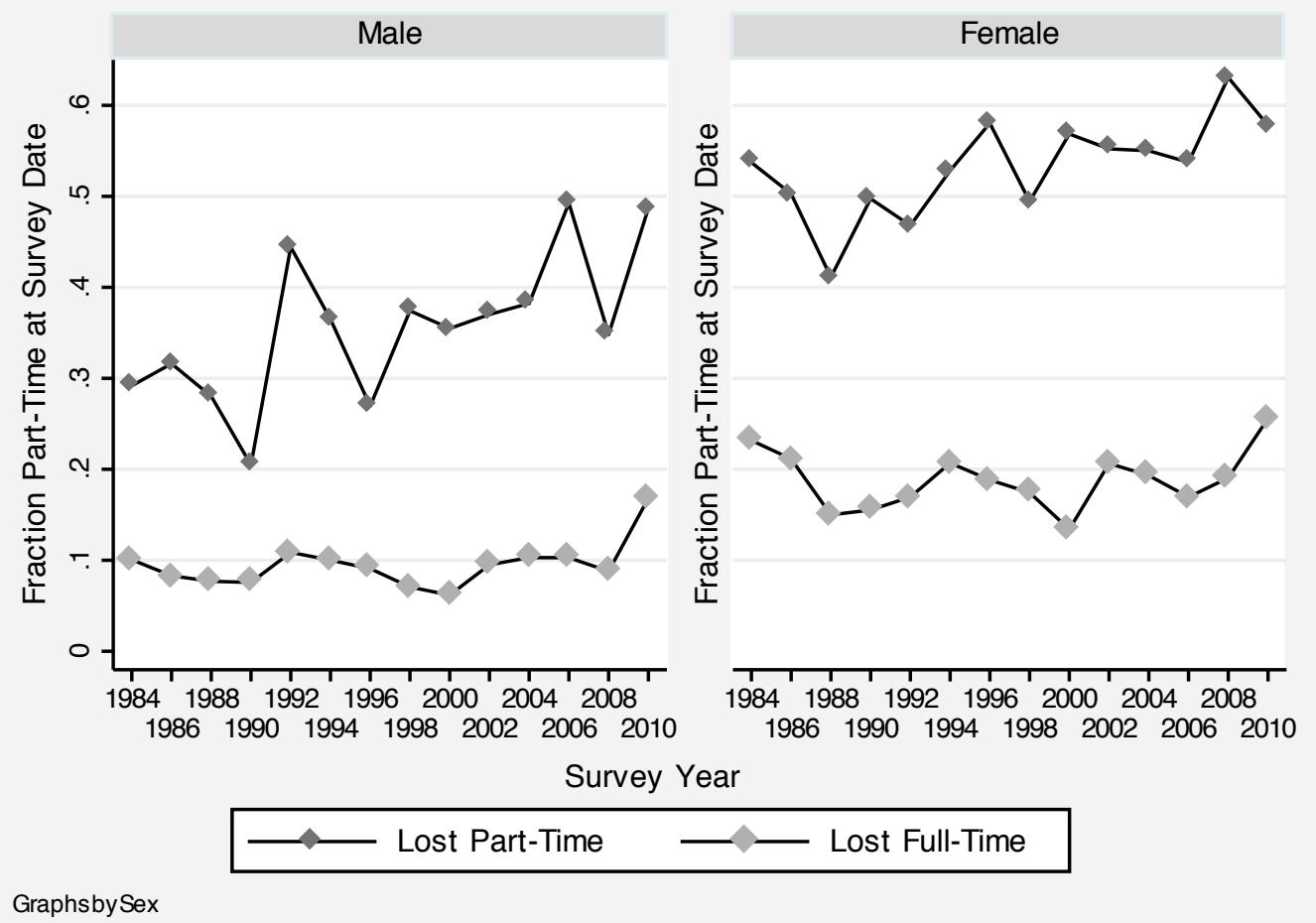

Figure 14: Fraction Part-Time at Survey Date, by Sex and Part-time Status on Lost Job

higher in each of the slack labor market periods. But the part-time rate was substantially higher in the Great Recession.

There are important differences by sex in the post-displacement part-time employment rate. In order to illustrate these differences, figure 14 contains separate plots for males and females of the fraction employed of job losers employed part-time at each survey date conditional on part-time status on the lost job. The post-displacement part-time rate is substantially higher (about 10 percentage points) among females, even controlling for parttime status on the lost job. This is consistent with the earlier finding that, relative to male job losers, female job losers are less likely to be employed and more likely to be out of the labor force. ${ }^{13}$ Despite the difference in levels by sex, the part-time rates for both men and women show a similar cyclical pattern, and there was a large increase in 2010 in part-time rates for both male and female full-time job losers.

\footnotetext{
13 Once again, this may be a labor supply response, reflecting the fact that some women have a richer set of alternative activities on which to spend time.
} 


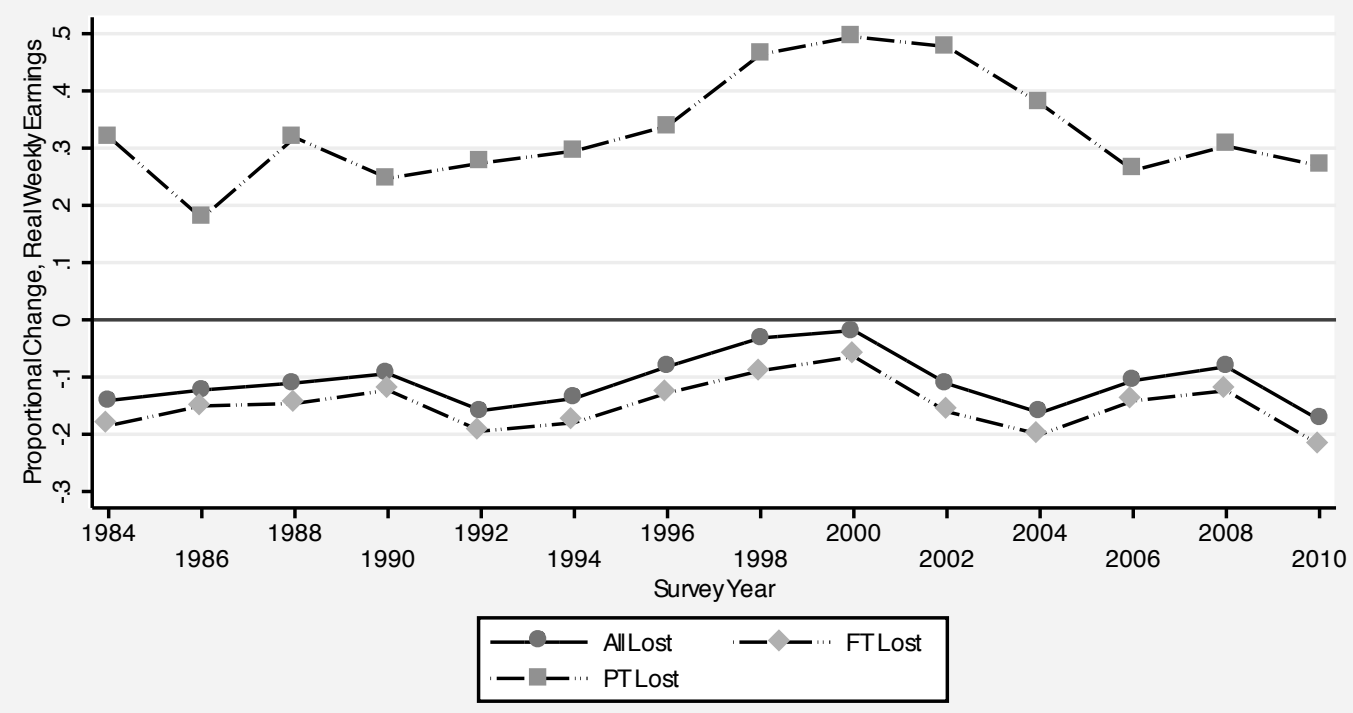

Figure 15: Proportional Change in Real Weekly Earnings, All Job Losers

\subsection{The Loss in Earnings Due to Displacement}

The analysis of the loss in earnings of re-employed displaced workers proceeds in two stages. First, I investigate the change in earnings between the lost job and the job held at the DWS survey date. However, had the displaced worker not lost his or her job, earnings likely would have grown over the interval between the date of job loss and the DWS survey date. Thus, second, I investigate the earnings loss suffered by displaced workers, including both the decline in earnings of the displaced workers and the increase in earnings enjoyed by nondisplaced workers that is foregone by displaced workers. In order to measure this earnings loss, a control group of non-displaced workers is required, and, later in this section, I provide such a control group using data from the CPS outgoing rotation groups.

\subsubsection{Difference Estimates of The Change in Earnings as a Result of Job Loss}

I begin the analysis of earnings changes by examining the difference in real weekly earnings for job losers between the post-displacement job and the job from which the worker was displaced. ${ }^{14}$ The solid line in figure 15 shows the average proportional decline, by survey year, in real weekly earnings between the lost job and the survey-date job for all workers

\footnotetext{
14 Earnings are deflated by the 1982-84=100 consumer price index (CPI). The CPI in the reported year of displacement is used to deflate earnings on the old job. The CPI for the DWS survey month is used to deflate current earnings.
} 


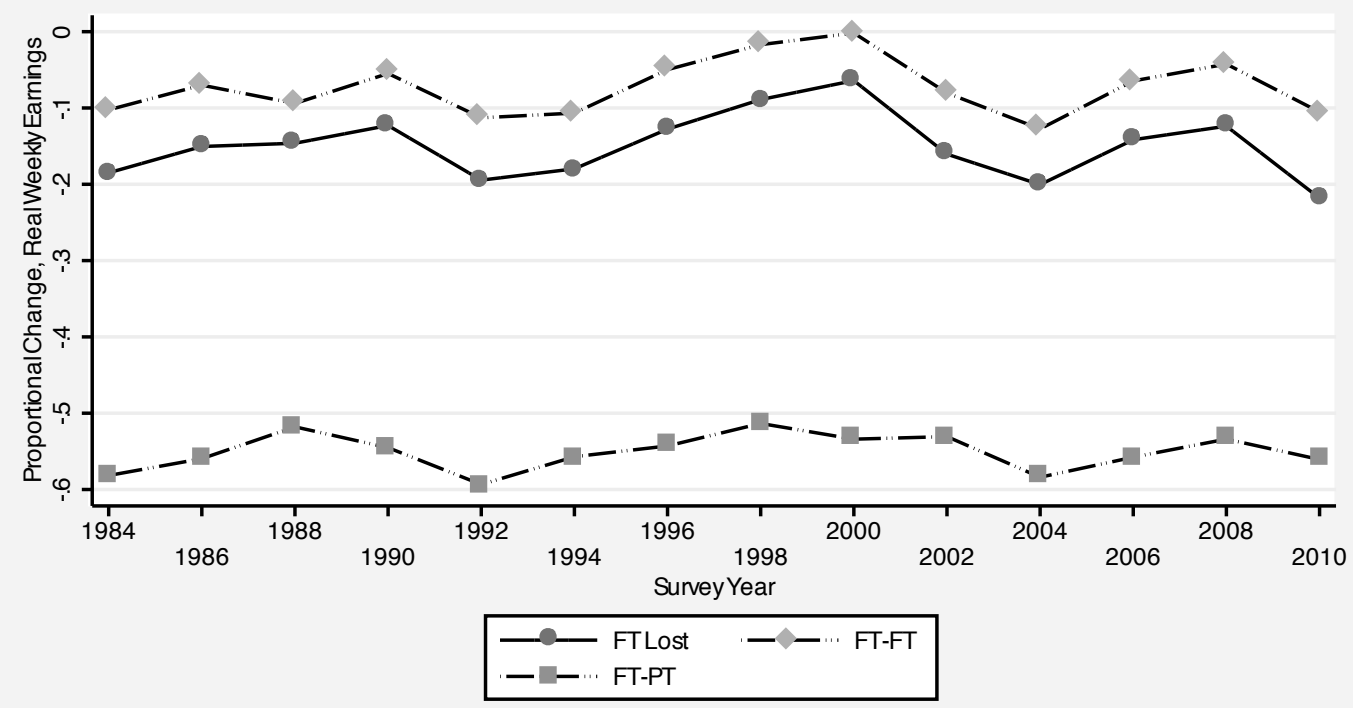

Figure 16: Proportional Change in Real Weekly Earnings, Full-Time Job Losers

who lost a job, were re-employed at the survey date, and were not self-employed on either the lost job or the new job. It is clear that there is a cyclical component to the earnings decline, with larger declines in slack labor market periods. The average earnings decline in the current recession is the largest since 1984 at 17.5 percent. This compares with a decline of 14.1 percent in 1984 and 15.9 percent in 1992.

Because my measure of earnings is weekly, part of the measured earnings change reflects voluntary or involuntary hours change (movement to or from full-time work). The lower dashed line in figure 15 is the average earnings change of full-time job losers. Not surprisingly, this closely parallels the earnings change of all job losers (correlation 0.986) because most reported loss is of full-time jobs (almost 90 percent). The reason full-time job losers have larger average earnings declines than the average is that some full-time workers are reemployed on part-time jobs (figure 13). The upper dashed line in figure 15 is the average earnings change of part-time job losers. this is positive in every period because many losers of part-time jobs are employed subsequently on full-time jobs (48 percent overall, figure 13). In summary, job losers suffer substantial earnings declines on average, and the average decline is largest in the most recent period.

Given that a large majority of job losers lost full-time jobs, I focus on the experience of these workers. The solid line in figure 16 reproduces the lower dashed line in figure 15 which is the average earnings change of full-time job losers. The upper dashed line in figure 16 is 


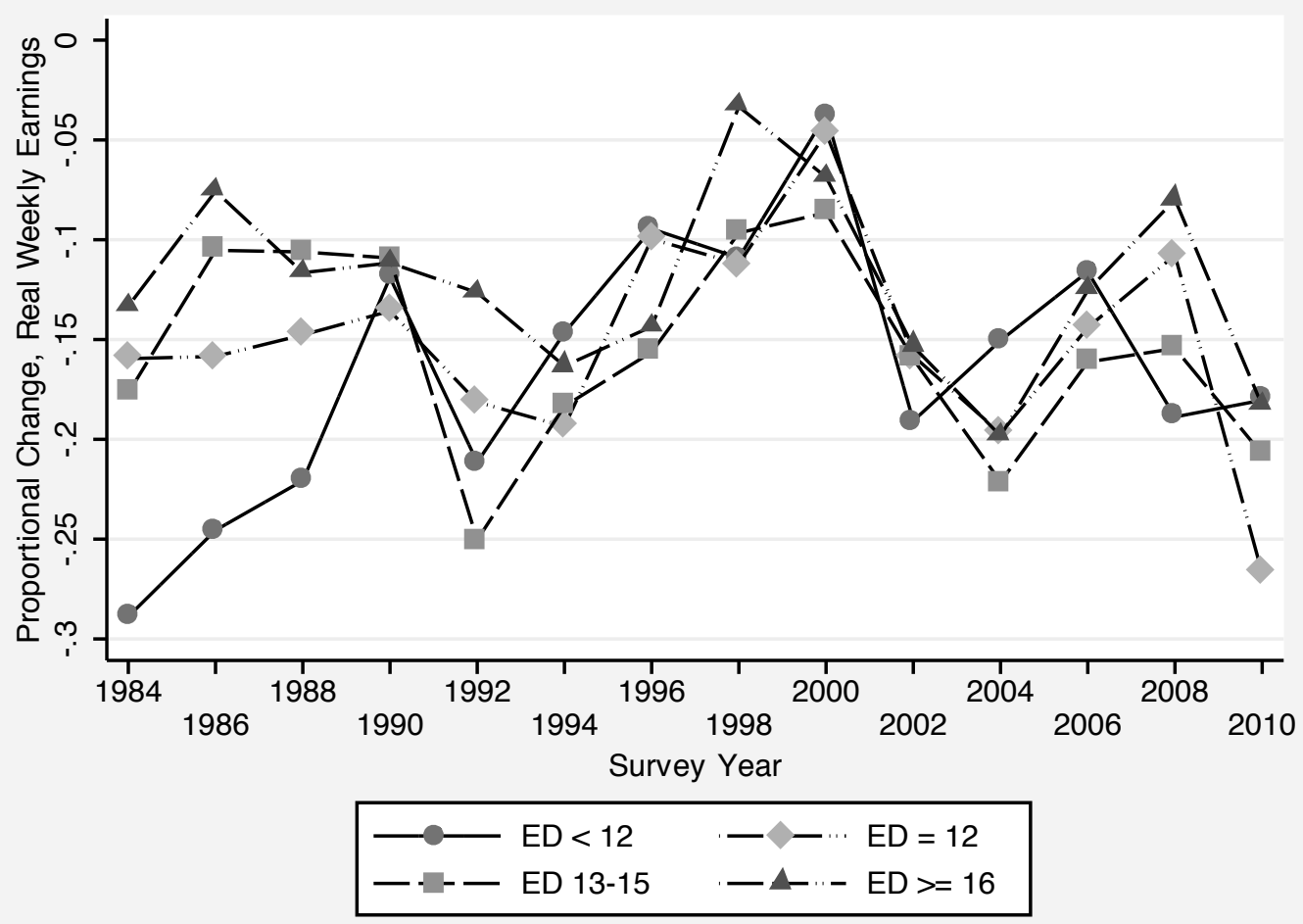

Figure 17: Average Decline in Log Weekly Earnings, by Year and Education, Full-Time Job Losers

the average earnings change of job losers who make a full-time to full-time transition. This closely parallels the earnings change of all full-time job losers (correlation 0.956) because most reemployed full-time job losers are re-employed full time. (87 percent). The lower dashed line in figure 16 is the average earnings change of job losers who have made a FT-PT transition. This is substantial and negative, because of the decline in weekly hours in moving from full-time to part-time.

All of these series show a cyclical pattern, with larger earnings declines in weaker labor markets. That this decline is largest in the most recent period is due entirely to the higher incidence of part-time employment on the new job among both full-time and part-time job losers. The earnings decline holding FT-PT status fixed is not particularly large in the current period relative to other slack labor market periods.

Figure 17 contains the average proportional change real weekly earnings between the lost job and the survey-date job for full-time job losers down by education. During the first part of the sample period (1981-1991), there were statistically significant differences in earnings changes across educational categories, with workers with more education suffering 
smaller earnings declines, on average, than workers with less education. However, between the early 1990s and 2006, the differences in earnings changes across educational groups are usually not statistically significant. There was a general decline in the earnings loss across educational categories during the 1990s that reversed in the early 2000s. Earnings losses are again substantial for all education groups in the most recent period, with high-school graduates seeing a 26.7 percent average decline in year weekly earnings and even college graduates suffering a 18.3 percent decline. An important point here is that since the early 1990s through the current period earnings losses have a strong cyclical component across all education groups.

While not presented here, I carried out a multivariate regression analysis of the log earnings change of displaced workers, controlling for year, education, age, race, sex, and tenure on the lost job. This analysis shows no significant relationship with race or sex. ${ }^{15}$ There is a strong relationship between age and the change in real earnings, with older workers suffering larger earnings declines. Job losers aged 55-64 earn 16 percent less than do job losers aged 25-34. Additionally, there is a very strong relationship between the change in earnings and tenure on the lost job. The average earnings loss is much larger when the worker had accumulated substantial tenure on the lost job. I estimate that workers who lose a job with 15 or more years of job tenure have an average earnings loss 27 percentage points larger than that of workers with less than one year of tenure on the lost job. This is consistent with the destruction of job or industry specific human capital when a long-term job ends. ${ }^{16}$

\subsubsection{Difference-in-Difference Estimates of the Effect of Job Loss on Earnings}

In order to account for the extent to which earnings might have grown had the workers not been displaced, I generate a comparison group of workers using a random sample from the merged outgoing rotation group (MOGRG) files of the CPS for the three calendar years prior to each DWS (period 0) together with all workers from the outgoing rotation groups of the CPSs containing the DWSs (period t). The data from MOGRG files of the CPS provides the period 0 earnings, and the data from the outgoing rotation rotation groups in the CPSs containing the DWSs provide the period $t$ earnings.

This analysis is restricted to full-time workers. In particular, the job losers considered are only those who are reemployed and make full-time to full-time transitions. As such, it

\footnotetext{
15 See Farber (2004) for presentation of regression results on the earnings change through the 2002 DWS.

16 Kletzer (1989), Neal (1995), and Parent (2000) address the issue of job loss and specific capital, both at the firm and industry level.
} 
will understate the true earnings loss of displacement for two reasons. First, it considers only those who are reemployed (50 percent of job losers in the most recent period). Second, it ignores the fact that many full-time job losers are reemployed in part-time jobs (about 20 percent in the most recent period), offset to some extent by those part-time job losers who are re-employed in full-time jobs.

Define the change in log real earnings for displaced workers as

$$
\Delta_{d}=\left(\ln W_{d t}-\ln W_{d 0}\right)
$$

and define the difference in log real earnings for workers in the comparison group as

$$
\Delta_{c}=\left(\ln W_{c t}-\ln W_{c 0}\right)
$$

where $d$ refers to displaced workers (the "treatment" group), $c$ refers to non-displaced workers (the "control" group), $t$ refers to "current" (post-displacement) period, and 0 refers to the "initial" (pre-displacement) period. The difference-in-difference estimate of the loss in log real weekly earnings due to job loss in is computed as

$$
\Delta \Delta=\Delta_{d}-\Delta_{c}
$$

Assuming average earnings would have grown rather than declined in the absence of displacement, $\Delta_{c}$ will be positive so that the difference-in-difference estimate of the average earnings decline $(\Delta \Delta)$ will be larger in absolute value than the simple difference estimate $\left(\Delta_{d}\right)$

I generate initial earnings for the comparison group $\left(\ln W_{g 0}\right)$ from a random sub-sample of the merged outgoing rotation group CPS file (MOGRG) each year from 1981-2009. ${ }^{17}$ The resulting comparison sample of initial earnings for full-time workers contains 154,272 observations.

17 The size of the random sample was set so that 1) the size of the sample with initial earnings on the control group was expected to be the same size as that with current earnings on the control group (two rotation groups) and 2) the distribution of years since the associated DWS survey date roughly mimicked the distribution of years since displacement in the sample of displaced workers. In other words, a separate control sample was drawn for each DWS from the three MOGRGs for the years immediately prior to the DWS that reflected the distribution of time since job loss. Each MOGRG file has 24 rotation groups (2 per month for 12 months). Denote the share of reported job loss one, two, and three years prior to the survey date $t$ as $p_{1 t}, p_{2 t}$, and $p_{3 t}$ respectively. In order to get the appropriate sample size in survey year $t, \mathrm{I}$ took a random sample with probability $\left(p_{1 t}\right)(2) / 24$. Similarly, for the second and third years prior to to the DWS I took random samples with probability $\left(p_{2 t}\right)(2) / 24$ and $\left(p_{3 t}\right)(2) / 24$, respectively. 
The CPSs containing the DWSs have two outgoing rotation groups (OGRGs) with earnings data for all workers. These provide the observations on current earnings for the comparison group of non-displaced workers $\left(\ln W_{g t}\right)$. This sample contains observations on full-time earnings for 150,935 workers at the DWS survey date.

Ideally, these comparison groups would contain only workers who had not lost a job during the relevant period. While I can identify the displaced workers in period $t$ (since the data come from the CPSs with DWSs), I cannot identify the workers who will be displaced in the MOGRG samples. To the extent that earnings growth for displaced workers is different from that for the non-displaced workers, earnings growth computed from the control group as defined here would lead to biased estimates of earnings growth for a group of non-displaced workers. In order to address this problem, I adjust the estimates based on the outgoing rotation groups to provide unbiased estimates of the earnings change for a control group of non-displaced workers. This adjustment is described in Appendix I.

The source of data for the treatment group earnings is clear. These data come from the DWSs, where $\ln W_{d t}$ is survey-date earnings for displaced workers and $\ln W_{d 0}$ is earnings on the lost job. The pre-displacement sample consists of all displaced workers who were not self-employed but were employed full-time on the lost job and who were employed with earnings available at the survey date $(n=26,788)$. The postdisplacement sample consists of all displaced workers who were not self-employed but were employed full-time at the survey date and who had earnings data available on the lost job $(n=24,057)$.

The difference-in-difference estimates are derived using these data from separate ordinary least squares (OLS) regressions for each DWS survey year of log real earnings (deflated by the CPI) on a set of worker characteristics and an indicator for time period (before or after displacement), an indicator for whether the observation is part of the "contaminated" control sample or part of the displacement sample, and the interaction of the time period and sample indicators. ${ }^{18}$ This is of the form year of the form

$$
\ln W_{i s}=X_{i s} \beta+\gamma_{1} T_{s}+\gamma_{2} D_{i}+\gamma_{3} T_{s} D_{i}+\epsilon_{i s}
$$

where $\ln W_{i s}$ measures log real full-time earnings for individual $i$ in period $s$ (either 0 or $t$ ), $X$ is a vector of individual characteristics, $\beta$ is a vector of coefficients, $T_{s}$ is a dummy variable indicating the post-displacement period, $D_{i}$ is a dummy variable indicating the displacement

\footnotetext{
18 Note that I do not calculate first-differenced estimates for the displaced workers, as I did in section 5.2.1, despite the fact that the observations are paired. This is because observations for the control group are from a set of cross-sections and are not paired. I do not account for the correlation over time in the two observations for each displaced worker.
} 

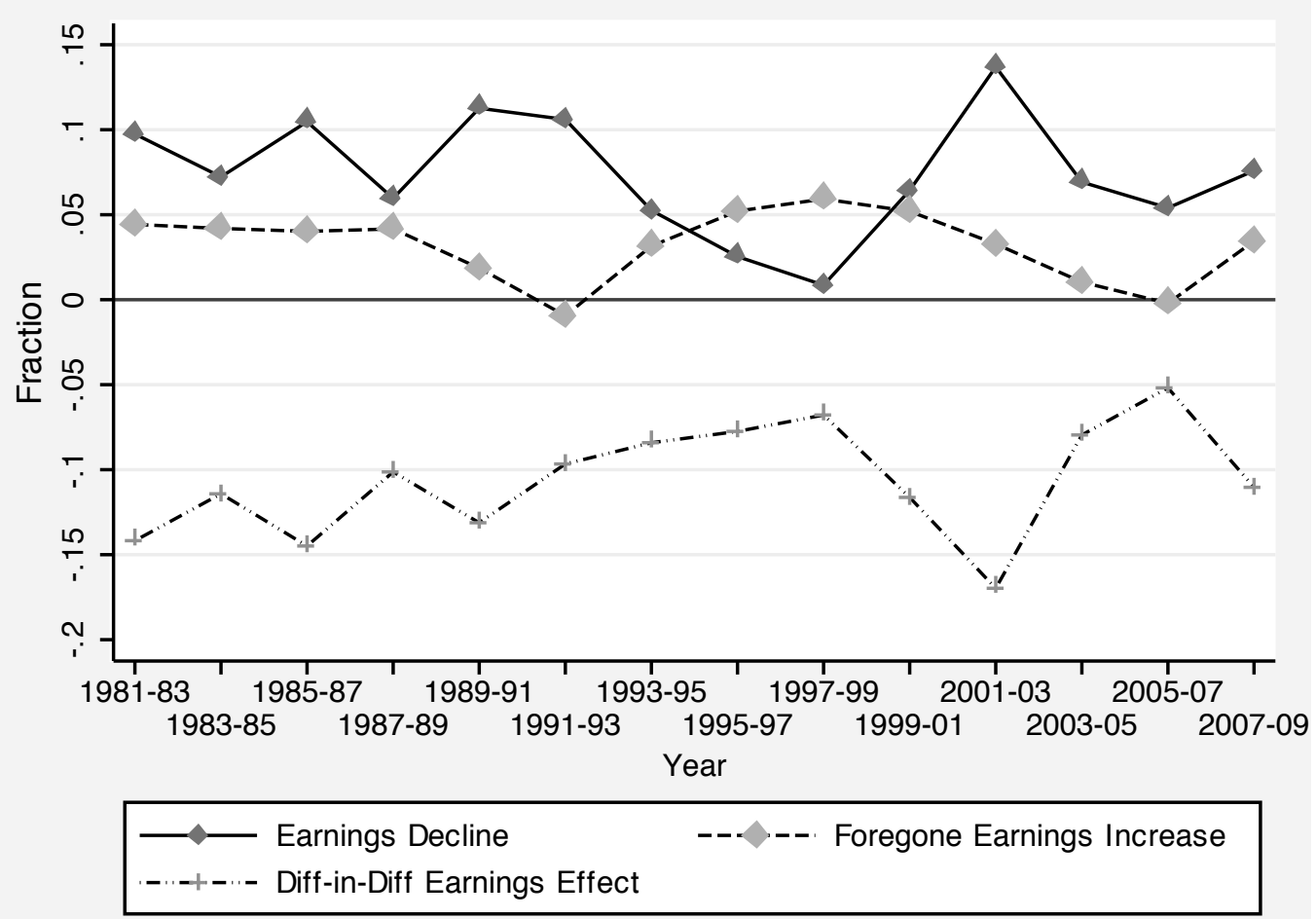

Figure 18: Proportional Earnings Loss, Difference-in Difference Analysis, FT-FT transitions.

sample, and $\epsilon$ is an error term. ${ }^{19}$ The estimates of the parameters $\gamma_{j}$ are used along with information from the DWS on period-specific job loss rates to compute estimates of the earnings effects as described in Appendix I.

Figure 18 contains the overall regression-adjusted difference-in-difference estimates of the proportional earnings loss from job loss for each year. ${ }^{20}$ In order for the figure to be clearly readable, the earnings loss for displaced workers in presented as a positive number (the negative of the earnings change for displaced workers: $-\Delta_{d}$ ). The foregone earnings increase is $\Delta_{c}$, and the difference-in-difference earnings effect is $\Delta \Delta$. Note that these estimates incorporate the effect of normal growth along the age-earnings profile. This is because the

19 The $X$ vector includes a constant, dummy variables for sex, race, nine age categories, and four educational categories.

${ }^{20}$ Note that the differences (or DIDs) in log earnings are approximations to the appropriate proportional differences (or DIDs) in earnings. I transform the differences in log earnings to proportional differences using the usual relationship that, with a $\log$ difference of $\delta$, the proportional difference is $e^{\delta}-1$. The differencein-difference estimate plotted in the figure is then calculated as the difference of the transformed differences $\left(\Delta \Delta=e^{\Delta_{d}}-e^{\Delta_{c}}\right)$. 
age variables in the regression are measured at the DWS survey date (period $t$ ) for both the period 0 and period $t$ observations. ${ }^{21}$

The results show that in the 1980s displaced workers earned about 9 percent less on average after displacement than before while earnings for the control group rose by about 4.5 percent over the same period. The difference-in-difference estimate of the earnings loss is the difference between these numbers, which is a loss of about 13 percent during the $1980 \mathrm{~s}^{22}$ The 1990s show a different pattern. The earnings decline of displaced workers in the 1990s dropped sharply during the decade, from 11.3 percent in the 1989-91 period to a statistically insignificant 0.9 percent in 1997-99. During the same period, the earnings growth of the control group increased from 1.9 percent in 1989-91 to 5.9 percent in 1997-99, reflecting the general increase in real wages in the late 1990s. The difference-in-difference estimate of the earnings loss associated with job loss decreased during the 1990s (from a high of 13.1 percent in 1989-91 to a low of 6.8 percent percent in 1997-99), reflecting the fact that the earnings decline suffered by displaced workers fell by more than earnings grew among the comparison group.

The picture changed in the last ten years. The foregone earnings increase fell somewhat from 5.9 percent in 1997-1999 to zero in 2005-2007 while the earnings decline suffered by displaced workers increased substantially from 0.9 percent in the 1997-99 period to 13.7 percent in 2001-03 before declining to 5.4 percent in 2005-2007. In the period covering the Great Recession (2007-09), the earnings decline of job losers making a FT-FT transition is 7.6 percent with a foregone earnings increase of 3.5 percent. This implies a total earnings loss from job displacement for these workers of 11 percent, which is not unusually large by historical standards.

It is clear from figures 18 that earnings growth foregone by job losers has been an important part of the cost of job loss in some periods. Interestingly, the period of the Great Recession has not been marked by unusually large real earnings losses for reemployed job losers making a FT-FT transition, The earnings loss in this period is split about $1 / 3$ forgone earnings growth and $2 / 3$ earnings decline.

\footnotetext{
21 This is one reason why it was important that the sample fractions in the initial-earnings control group mimic the fractions in the treatment group with respect to the time until the DWS survey date.

${ }^{22}$ Since in the figure I present the earnings loss rather than the earnings change for displaced workers, the difference-in-difference estimate is the negative of the sum of the earnings decline for displaced workers and the foregone earnings increase.
} 


\section{Concluding Remarks}

Job loss and worker dislocation are facts of life in the U.S. economy, and they are part of an efficient labor allocation process. However, the costs of job loss have been particularly severe in the Great Recession. During this period (job loss in 2007-2009) I find that

- About 16 percent of people aged 20-64 reported having lost a job.

- Less than 50 percent of job losers are employed in January 2010 (a much lower fraction than in earlier periods).

- While reemployed job losers did not suffer particularly long spells of unemployment, the large number of job losers who did not find a new job have very long spells of unemployment. This is reinforced by the extremely long durations of spells of unemployment in progress reported in the basic CPS (a mean of about 35 weeks in 2010).

- About 20 percent re-employed full-time job losers are holding part-time jobs (a much higher fraction than in earlier period).

- Job losers who found new jobs earned on average 17.5 percent less on average on their new jobs than on the lost job, and losers of full-time jobs earnings 21.8 percent less on average than on the lost job.

- Counting foregone earnings increases enjoyed by non-losers, full-time job losers who find new full-time jobs suffered a total earnings loss of about 11 percent less on average on their new jobs than they would have had they not been displaced.

The measures I focused on likely substantially understate the true economic cost of job loss. First, time spent unemployed by those workers who are re-employed is not considered. Second, more hinges on employment, particularly full-time employment, in the U.S. than in other developed countries. Health insurance and pensions are closely linked to employment, and many workers do not have alternative access to these important benefits. This makes job loss an expensive and damaging event on average.

To conclude, while job loss is a fact of life in the U.S., the consequences of job loss in the Great Recession have been unusually severe. Most importantly, job losers in the Great Recession have been much less successful at finding new jobs (particularly full-time jobs) than in the aftermath of earlier recessions. It is not yet clear what the long run consequences of prolonged inability to find work for job losers on their future labor market outcomes will be. 


\section{References}

Fallick, Bruce C. "A Review of the Recent Empirical Literature on Displaced Workers," Industrial and Labor Relations Review 50 (October 1996): pp. 5-16.

Farber, Henry S. "The Incidence and Costs of Job Loss: 1982-91," Brookings Papers on Economic Activity: Microeconomics, (1993,1), 73-119.

Farber, Henry S. "The Changing Face of Job Loss in the United States, 1981-1995," Brookings Papers on Economic Activity: Microeconomics, 1997: 55-128.

Farber, Henry S. "Has the Rate of Job Loss Increased in the Nineties?" Proceedings of the Fiftieth Annual Winter Meeting of the Industrial Relations Research Association, Volume 1, 1998: pp. 88-97.

Farber, Henry S. "Job Loss in the United States, 1981-2001," Research in Labor Economics 23 (2004), pp. 69-117.

Farber, Henry S. "What do we know about Job Loss in the United States? Evidence from the Displaced Workers Survey, 1981-2004," Economic Perspectives, Federal Reserve Bank of Chicago (Second Quarter, 2005), pp. 13-28.

Farber, Henry S. and Helen Levy "Recent Trends in Employer-Sponsered Health Insurance Coverage: Are Bad Jobs Getting Worse?" Journal of Health Economics, January 2000. pp. 93-119.

Gardner, Jennifer M. "Worker Displacement: A Decade of Change," Monthly Labor Review 118 (April 1995): pp. 45-57.

Hipple, Steven. "Worker Displacement in the mid-1990's," Monthly Labor Review 122 (July 1999): pp. 15-32.

Kletzer, Lori G. "Returns to Seniority after Permanent Job Loss," American Economic Review 79 (June 1989): pp. 536-543.

National Bureau of Economic Research. "The NBER's Business Cycle Dating Committee," September 20, 2010. Available at http://www.nber.org/cycles/recessions.html 
Neal, Derek. "Industry-Specific Capital: Evidence from Displaced Workers," Journal of Labor Economics 13 (October 1995): pp. 653-677.

Parent, Daniel. "IndustrySpecific Capital and the Wage Profile: Evidence from the National Longitudinal Survey of Youth and the Panel Study of Income Dynamics, " Journal of Labor Economics 18 (April 2000): pp. 306-323.

Podgursky, Michael and Paul Swaim. "Job Displacement Earnings Loss: Evidence from the Displaced Worker Survey,"” Industrial and Labor Relations Review 41 (October 1987): pp. 17-29.

Polivka, Anne E. and Stephen M. Miller. "The CPS After the Redesign: Refocusing the Lens," in Labor Statistics Measurement Issues, John Haltiwanger, Marilyn Manser, and Robert Topel, eds., University of Chicago Press, 1998. pp. 249-289.

Topel, Robert. "Specific Capital and Unemployment: Measuring the Costs and Consequences of Job Loss," Carnegie Rochester Conference Series on Public Policy 33 (1990): pp. 181-214. 


\section{APPENDIX I - Details of the Difference-In-Difference Procedure}

The observed log wage change of workers in the outgoing rotation groups (which include both displaced and non-displaced workers) is a probability-of-job-loss weighted average of the change in log earnings for displaced and non-displaced workers. Define the change in log earnings for the outgoing rotation groups as

$$
\Delta_{g}=(1-\theta) \Delta_{c}+\theta \Delta_{d}
$$

where $\Delta_{g}$ is the log earnings change in the outgoing rotation group sample $\left(\ln W_{g t}-\ln W_{g 0}\right)$ and $\theta$ is the fraction of workers in the outgoing rotation group sample who lost a job (the displacement rate).

The observable quantities are $\Delta_{g}$ and $\Delta_{d}$, but calculation of the difference-in-difference estimate of the log earnings change due to job loss requires both $\Delta_{d}$ and $\Delta_{c}$ (equations 1 and 2). ${ }^{23}$ I can compute $\Delta_{c}$ with the available data on $\Delta_{g}, \Delta_{d}$, and $\theta$. Using equation 5 , the change in log earnings for the comparison group is

$$
\Delta_{c}=\frac{\Delta_{g}-\theta \Delta_{d}}{(1-\theta)},
$$

and the difference-in-difference estimate of the effect of job loss on earnings is

$$
\Delta \Delta=\frac{\Delta_{d}-\Delta_{g}}{(1-\theta)}
$$

Intuitively, the samples from the outgoing rotation groups are "contaminated" with displaced workers so that the difference-in-difference estimate computed using this contaminated control group need to be scaled up by the factor $\frac{1}{(1-\theta)}$ to compensate.

The parameters $\gamma_{j}$, estimated by separate OLS regressions for each DWS survey year from equation 4, are used along with information from the DWS on period-specific job loss rates $(\theta)$ to compute estimates of the log earnings effects as follows:

$$
\begin{aligned}
\Delta_{d} & =\gamma_{1}+\gamma_{3} \\
\Delta_{c} & =\gamma_{1}-\frac{\theta \gamma_{3}}{(1-\theta)}, \text { and } \\
\Delta \Delta & =\frac{\gamma_{3}}{(1-\theta)}
\end{aligned}
$$

\footnotetext{
23 Note that I do not use the information on who is displaced that is available in the DWS outgoing rotation groups. My estimate of $\Delta_{g}$ includes both displaced and non-displaced workers at both time 0 and time $t$.
} 


\section{APPENDIX II - Data underlying Figures}

Appendix Table 3:

Three-Year Rate of Job Loss and Unemployment Rate, 1981-2009

(Numbers for Figure 3)

All Individuals

\begin{tabular}{l|rr} 
Year & Job-Loss Rate & Unemployment Rate \\
\hline $1981-83$ & 12.8 & 9.6 \\
$1983-85$ & 10.3 & 7.2 \\
$1985-87$ & 9.5 & 6.2 \\
$1987-89$ & 8.5 & 5.3 \\
$1989-91$ & 11.8 & 6.8 \\
$1991-93$ & 10.9 & 6.9 \\
$1993-95$ & 11.5 & 5.6 \\
$1995-97$ & 9.1 & 4.9 \\
$1997-99$ & 8.6 & 4.2 \\
$1999-01$ & 11.1 & 4.7 \\
$2001-03$ & 11.8 & 6.0 \\
$2003-05$ & 8.5 & 5.1 \\
$2005-07$ & 8.5 & 4.6 \\
$2007-09$ & 16.0 & 9.3
\end{tabular}

Appendix Table 4:

Three-Year Rate of Job Loss by Education, 1981-2009

(Numbers for Figure 4)

\begin{tabular}{l|cccc} 
Year & ED $<12$ & ED $=12$ & ED 13-15 & ED $\geq 16$ \\
\hline $1981-83$ & 0.186 & 0.143 & 0.118 & 0.069 \\
$1983-85$ & 0.149 & 0.115 & 0.096 & 0.059 \\
$1985-87$ & 0.134 & 0.104 & 0.095 & 0.059 \\
$1987-89$ & 0.121 & 0.094 & 0.083 & 0.054 \\
$1989-91$ & 0.175 & 0.129 & 0.113 & 0.082 \\
$1991-93$ & 0.143 & 0.118 & 0.115 & 0.079 \\
$1993-95$ & 0.154 & 0.122 & 0.123 & 0.084 \\
$1996-97$ & 0.131 & 0.096 & 0.096 & 0.069 \\
$1997-99$ & 0.122 & 0.090 & 0.091 & 0.067 \\
$1999-01$ & 0.156 & 0.117 & 0.115 & 0.088 \\
$2001-03$ & 0.164 & 0.124 & 0.120 & 0.099 \\
$2003-05$ & 0.117 & 0.095 & 0.088 & 0.066 \\
$2005-07$ & 0.136 & 0.097 & 0.088 & 0.060 \\
$2007-09$ & 0.254 & 0.194 & 0.164 & 0.110
\end{tabular}


Appendix Table 5:

Three-Year Rate of Job Loss by Age, 1981-2009

(Numbers for Figure 5)

\begin{tabular}{l|cccc} 
Year & Age 20-24 & Age 25-44 & Age 45-54 & Age 55-64 \\
\hline $1981-83$ & 0.159 & 0.128 & 0.099 & 0.100 \\
$1983-85$ & 0.118 & 0.107 & 0.085 & 0.086 \\
$1985-87$ & 0.104 & 0.099 & 0.087 & 0.082 \\
$1987-89$ & 0.094 & 0.091 & 0.075 & 0.071 \\
$1989-91$ & 0.137 & 0.117 & 0.106 & 0.104 \\
$1991-93$ & 0.119 & 0.110 & 0.100 & 0.106 \\
$1993-95$ & 0.140 & 0.114 & 0.105 & 0.097 \\
$1996-97$ & 0.104 & 0.092 & 0.084 & 0.084 \\
$1997-99$ & 0.097 & 0.085 & 0.083 & 0.080 \\
$1999-01$ & 0.136 & 0.117 & 0.097 & 0.094 \\
$2001-03$ & 0.129 & 0.127 & 0.109 & 0.108 \\
$2003-05$ & 0.093 & 0.085 & 0.082 & 0.083 \\
$2005-07$ & 0.102 & 0.082 & 0.080 & 0.078 \\
$2007-09$ & 0.176 & 0.170 & 0.154 & 0.144
\end{tabular}

Appendix Table 6:

Post-Displacement Labor Force Status, 1984-2010

(Numbers for Figure 6)

\begin{tabular}{l|ccc} 
Year & Employed & Unemployed & NILF \\
\hline $1981-83$ & 0.589 & 0.286 & 0.124 \\
$1983-85$ & 0.639 & 0.238 & 0.123 \\
$1985-87$ & 0.682 & 0.206 & 0.112 \\
$1987-89$ & 0.706 & 0.191 & 0.103 \\
$1989-91$ & 0.604 & 0.286 & 0.110 \\
$1991-93$ & 0.669 & 0.217 & 0.114 \\
$1993-95$ & 0.713 & 0.172 & 0.115 \\
$1996-97$ & 0.763 & 0.130 & 0.107 \\
$1997-99$ & 0.730 & 0.150 & 0.120 \\
$1999-01$ & 0.614 & 0.267 & 0.119 \\
$2001-03$ & 0.646 & 0.240 & 0.115 \\
$2003-05$ & 0.658 & 0.201 & 0.141 \\
$2005-07$ & 0.650 & 0.232 & 0.118 \\
$2007-09$ & 0.474 & 0.402 & 0.124
\end{tabular}


Appendix Table 7:

Post-Displacement Labor Force Status, 1984-2010, by Sex

(Numbers for Figure 7)

Male Female

\begin{tabular}{l|ccc|ccc} 
Year & Employed & Unemployed & NILF & Employed & Unemployed & NILF \\
\hline $1981-83$ & 0.625 & 0.308 & 0.066 & 0.528 & 0.249 & 0.223 \\
$1983-85$ & 0.660 & 0.266 & 0.074 & 0.605 & 0.193 & 0.202 \\
$1985-87$ & 0.710 & 0.223 & 0.067 & 0.640 & 0.180 & 0.180 \\
$1987-89$ & 0.731 & 0.205 & 0.064 & 0.671 & 0.172 & 0.156 \\
$1989-91$ & 0.612 & 0.316 & 0.072 & 0.591 & 0.241 & 0.168 \\
$1991-93$ & 0.694 & 0.233 & 0.073 & 0.632 & 0.193 & 0.174 \\
$1993-95$ & 0.738 & 0.196 & 0.067 & 0.679 & 0.141 & 0.179 \\
$1996-97$ & 0.795 & 0.142 & 0.063 & 0.723 & 0.116 & 0.161 \\
$1997-99$ & 0.771 & 0.155 & 0.074 & 0.683 & 0.143 & 0.174 \\
$1999-01$ & 0.630 & 0.285 & 0.085 & 0.592 & 0.243 & 0.165 \\
$2001-03$ & 0.668 & 0.253 & 0.079 & 0.614 & 0.222 & 0.164 \\
$2003-05$ & 0.693 & 0.206 & 0.102 & 0.614 & 0.194 & 0.192 \\
$2005-07$ & 0.668 & 0.255 & 0.077 & 0.624 & 0.200 & 0.176 \\
$2007-09$ & 0.472 & 0.433 & 0.095 & 0.477 & 0.351 & 0.17
\end{tabular}


Appendix Table 8:

Post-Displacement Labor Force Status, 1984-2004, by Education (Numbers for Figure 8)

$$
\mathrm{ED}<12 \quad \mathrm{ED}=12
$$

\begin{tabular}{l|ccc|ccc} 
Year & Employed & Unemployed & NILF & Employed & Unemployed & NILF \\
\hline $1981-83$ & 0.442 & 0.395 & 0.162 & 0.586 & 0.290 & 0.124 \\
$1983-85$ & 0.480 & 0.333 & 0.187 & 0.639 & 0.240 & 0.121 \\
$1985-87$ & 0.593 & 0.270 & 0.137 & 0.648 & 0.231 & 0.121 \\
$1987-89$ & 0.587 & 0.253 & 0.160 & 0.677 & 0.215 & 0.108 \\
$1989-91$ & 0.441 & 0.376 & 0.183 & 0.566 & 0.326 & 0.108 \\
$1991-93$ & 0.499 & 0.329 & 0.171 & 0.636 & 0.247 & 0.117 \\
$1993-95$ & 0.577 & 0.287 & 0.136 & 0.685 & 0.185 & 0.130 \\
$1996-97$ & 0.623 & 0.217 & 0.160 & 0.743 & 0.146 & 0.111 \\
$1997-99$ & 0.578 & 0.245 & 0.177 & 0.706 & 0.159 & 0.135 \\
$1999-01$ & 0.497 & 0.348 & 0.155 & 0.568 & 0.298 & 0.134 \\
$2001-03$ & 0.547 & 0.305 & 0.148 & 0.620 & 0.251 & 0.129 \\
$2003-05$ & 0.531 & 0.291 & 0.178 & 0.625 & 0.231 & 0.144 \\
$2005-07$ & 0.486 & 0.353 & 0.160 & 0.628 & 0.255 & 0.117 \\
$2007-09$ & 0.385 & 0.477 & 0.137 & 0.413 & 0.457 & 0.131
\end{tabular}

ED 13-15

$\mathrm{ED} \geq 16$

\begin{tabular}{l|ccc|ccc} 
Year & Employed & Unemployed & NILF & Employed & Unemployed & NILF \\
\hline $1981-83$ & 0.648 & 0.235 & 0.117 & 0.779 & 0.152 & 0.069 \\
$1983-85$ & 0.695 & 0.205 & 0.100 & 0.800 & 0.132 & 0.068 \\
$1985-87$ & 0.745 & 0.157 & 0.098 & 0.808 & 0.123 & 0.069 \\
$1987-89$ & 0.781 & 0.136 & 0.082 & 0.815 & 0.133 & 0.052 \\
$1989-91$ & 0.662 & 0.230 & 0.108 & 0.744 & 0.201 & 0.054 \\
$1991-93$ & 0.704 & 0.191 & 0.105 & 0.785 & 0.131 & 0.085 \\
$1993-95$ & 0.734 & 0.151 & 0.115 & 0.805 & 0.119 & 0.075 \\
$1996-97$ & 0.785 & 0.108 & 0.107 & 0.846 & 0.087 & 0.068 \\
$1997-99$ & 0.747 & 0.138 & 0.115 & 0.815 & 0.106 & 0.079 \\
$1999-01$ & 0.653 & 0.228 & 0.119 & 0.679 & 0.238 & 0.083 \\
$2001-03$ & 0.646 & 0.240 & 0.114 & 0.717 & 0.200 & 0.083 \\
$2003-05$ & 0.656 & 0.177 & 0.168 & 0.762 & 0.151 & 0.087 \\
$2005-07$ & 0.681 & 0.198 & 0.122 & 0.723 & 0.185 & 0.093 \\
$2007-09$ & 0.492 & 0.371 & 0.137 & 0.585 & 0.325 & 0.090
\end{tabular}


Appendix Table 9:

Post-Displacement Labor Force Status, 1984-2004, by Age

(Numbers for Figure 9)

Age 20-24

Age 25-44

\begin{tabular}{l|ccc|ccc} 
Year & Employed & Unemployed & NILF & Employed & Unemployed & NILF \\
\hline $1981-83$ & 0.605 & 0.282 & 0.112 & 0.632 & 0.266 & 0.101 \\
$1983-85$ & 0.632 & 0.258 & 0.110 & 0.675 & 0.232 & 0.093 \\
$1985-87$ & 0.674 & 0.223 & 0.102 & 0.716 & 0.202 & 0.082 \\
$1987-89$ & 0.689 & 0.217 & 0.094 & 0.740 & 0.175 & 0.085 \\
$1989-91$ & 0.559 & 0.303 & 0.138 & 0.634 & 0.279 & 0.087 \\
$1991-93$ & 0.620 & 0.245 & 0.135 & 0.706 & 0.204 & 0.090 \\
$1993-95$ & 0.693 & 0.186 & 0.121 & 0.740 & 0.164 & 0.095 \\
$1996-97$ & 0.718 & 0.158 & 0.124 & 0.801 & 0.118 & 0.081 \\
$1997-99$ & 0.684 & 0.172 & 0.143 & 0.762 & 0.146 & 0.092 \\
$1999-01$ & 0.604 & 0.280 & 0.116 & 0.629 & 0.268 & 0.103 \\
$2001-03$ & 0.607 & 0.267 & 0.126 & 0.672 & 0.227 & 0.100 \\
$2003-05$ & 0.594 & 0.255 & 0.151 & 0.686 & 0.197 & 0.116 \\
$2005-07$ & 0.645 & 0.229 & 0.126 & 0.667 & 0.236 & 0.097 \\
$2007-09$ & 0.459 & 0.384 & 0.157 & 0.504 & 0.391 & 0.106
\end{tabular}

Age 45-54

Age 55-64

\begin{tabular}{l|ccc|ccc} 
Year & Employed & Unemployed & NILF & Employed & Unemployed & NILF \\
\hline $1981-83$ & 0.544 & 0.314 & 0.142 & 0.346 & 0.384 & 0.270 \\
$1983-85$ & 0.604 & 0.259 & 0.137 & 0.461 & 0.209 & 0.330 \\
$1985-87$ & 0.644 & 0.203 & 0.152 & 0.513 & 0.212 & 0.275 \\
$1987-89$ & 0.671 & 0.236 & 0.093 & 0.536 & 0.204 & 0.259 \\
$1989-91$ & 0.590 & 0.307 & 0.103 & 0.483 & 0.272 & 0.244 \\
$1991-93$ & 0.648 & 0.245 & 0.106 & 0.527 & 0.218 & 0.255 \\
$1993-95$ & 0.718 & 0.176 & 0.106 & 0.524 & 0.206 & 0.270 \\
$1996-97$ & 0.757 & 0.152 & 0.092 & 0.608 & 0.125 & 0.267 \\
$1997-99$ & 0.754 & 0.144 & 0.102 & 0.572 & 0.155 & 0.273 \\
$1999-01$ & 0.633 & 0.260 & 0.107 & 0.500 & 0.259 & 0.241 \\
$2001-03$ & 0.647 & 0.255 & 0.098 & 0.551 & 0.250 & 0.198 \\
$2003-05$ & 0.682 & 0.191 & 0.127 & 0.564 & 0.188 & 0.247 \\
$2005-07$ & 0.666 & 0.219 & 0.115 & 0.567 & 0.243 & 0.190 \\
$2007-09$ & 0.465 & 0.429 & 0.106 & 0.393 & 0.411 & 0.196
\end{tabular}


Appendix Table 10:

Fraction Ever Employed Subsequent to Job Loss, by Time Since Job Loss. Job and Year (Numbers for Figure 10)

\begin{tabular}{r|rrr} 
Year & 1 yr ago & $>$ 1yr ago & All \\
\hline 1986 & 0.590 & 0.866 & 0.746 \\
1988 & 0.632 & 0.886 & 0.786 \\
1990 & 0.617 & 0.908 & 0.785 \\
1992 & 0.539 & 0.846 & 0.703 \\
1994 & 0.611 & 0.856 & 0.751 \\
1996 & 0.694 & 0.885 & 0.794 \\
1998 & 0.721 & 0.911 & 0.829 \\
2000 & 0.734 & 0.899 & 0.824 \\
2002 & 0.583 & 0.863 & 0.709 \\
2004 & 0.580 & 0.855 & 0.741 \\
2006 & 0.620 & 0.869 & 0.759 \\
2008 & 0.597 & 0.870 & 0.741 \\
2010 & 0.443 & 0.690 & 0.563
\end{tabular}

Appendix Table 11:

Fraction Employed at Survey Date

Conditional on Holding at Least One Post- Displacement Job

By Time Since Job Loss.

(Numbers for Figure 11)

\begin{tabular}{r|rr} 
Year & 1 yr ago & $>1$ yr ago \\
\hline 1986 & 0.851 & 0.856 \\
1988 & 0.863 & 0.868 \\
1990 & 0.914 & 0.891 \\
1992 & 0.875 & 0.846 \\
1994 & 0.894 & 0.885 \\
1996 & 0.904 & 0.887 \\
1998 & 0.902 & 0.927 \\
2000 & 0.908 & 0.900 \\
2002 & 0.888 & 0.883 \\
2004 & 0.884 & 0.897 \\
2006 & 0.903 & 0.882 \\
2008 & 0.880 & 0.904 \\
2010 & 0.855 & 0.851
\end{tabular}


Appendix Table 12:

Weeks of Unemployment Before Finding New Job

Conditional on Holding at Least One Post-Displacement Job.

(Numbers for Figure 12)

\begin{tabular}{r|rr} 
Year & $\begin{array}{r}\text { Mean } \\
\text { Weeks }\end{array}$ & Wedian \\
& Weeks \\
\hline 1988 & 13.8 & 6.0 \\
1990 & 11.2 & 5.0 \\
1992 & 12.6 & 6.0 \\
1996 & 11.8 & 5.0 \\
1998 & 11.0 & 4.0 \\
2000 & 9.4 & 4.0 \\
2002 & 9.0 & 4.0 \\
2004 & 14.5 & 7.0 \\
2006 & 13.0 & 6.0 \\
2008 & 10.5 & 4.0 \\
2010 & 13.4 & 8.0
\end{tabular}

Appendix Table 13:

Fraction Part-Time at Survey Date, by Part-time Status on Lost Job and Year (Numbers for Figure 13)

\begin{tabular}{l|rr} 
Year & Old PT & Old FT \\
\hline $1981-83$ & 0.445 & 0.139 \\
$1983-85$ & 0.439 & 0.126 \\
$1985-87$ & 0.370 & 0.101 \\
$1987-89$ & 0.407 & 0.105 \\
$1989-91$ & 0.460 & 0.131 \\
$1991-93$ & 0.458 & 0.138 \\
$1993-95$ & 0.484 & 0.127 \\
$1996-97$ & 0.451 & 0.111 \\
$1997-99$ & 0.505 & 0.091 \\
$1999-01$ & 0.483 & 0.140 \\
$2001-03$ & 0.487 & 0.137 \\
$2003-05$ & 0.522 & 0.128 \\
$2005-07$ & 0.522 & 0.126 \\
$2007-09$ & 0.539 & 0.200
\end{tabular}


Appendix Table 14:

Fraction Part-Time at Survey Date, by Sex and Part-time Status on Lost Job and Year (Numbers for Figure 14)

\begin{tabular}{l|cc|cc} 
& \multicolumn{2}{c}{ Male } & \multicolumn{2}{c}{ Female } \\
Year & Old PT & Old FT & Old PT & Old FT \\
\hline $1981-83$ & 0.292 & 0.101 & 0.537 & 0.232 \\
$1983-85$ & 0.316 & 0.083 & 0.503 & 0.211 \\
$1985-87$ & 0.280 & 0.077 & 0.411 & 0.150 \\
$1987-89$ & 0.205 & 0.076 & 0.497 & 0.155 \\
$1989-91$ & 0.444 & 0.109 & 0.468 & 0.169 \\
$1991-93$ & 0.365 & 0.100 & 0.528 & 0.207 \\
$1993-95$ & 0.270 & 0.091 & 0.580 & 0.188 \\
$1996-97$ & 0.374 & 0.071 & 0.494 & 0.174 \\
$1997-99$ & 0.355 & 0.062 & 0.569 & 0.134 \\
$1999-01$ & 0.370 & 0.095 & 0.552 & 0.206 \\
$2001-03$ & 0.382 & 0.103 & 0.550 & 0.193 \\
$2003-05$ & 0.493 & 0.103 & 0.537 & 0.169 \\
$2005-07$ & 0.348 & 0.088 & 0.631 & 0.191 \\
$2007-09$ & 0.487 & 0.168 & 0.578 & 0.256
\end{tabular}

Appendix Table 15:

Proportional Change in Real Weekly Earnings, All Job Losers

(Numbers for Figure 15)

\begin{tabular}{r|rrr} 
Year & All Lost & FT Lost & PT Lost \\
\hline 1984 & -0.141 & -0.185 & 0.320 \\
1986 & -0.123 & -0.150 & 0.178 \\
1988 & -0.110 & -0.146 & 0.319 \\
1990 & -0.094 & -0.123 & 0.247 \\
1992 & -0.159 & -0.195 & 0.274 \\
1994 & -0.137 & -0.180 & 0.295 \\
1996 & -0.082 & -0.128 & 0.339 \\
1998 & -0.032 & -0.089 & 0.464 \\
2000 & -0.019 & -0.064 & 0.495 \\
2002 & -0.112 & -0.161 & 0.477 \\
2004 & -0.162 & -0.200 & 0.378 \\
2006 & -0.106 & -0.142 & 0.261 \\
2008 & -0.082 & -0.124 & 0.304 \\
2010 & -0.175 & -0.218 & 0.269
\end{tabular}


Appendix Table 16:

Proportional Change in Real Weekly Earnings, Full-Time Job Losers

(Numbers for Figure 16)

\begin{tabular}{r|rrr} 
Year & FT Lost & FT-FT & FT-PT \\
\hline 1984 & -0.185 & -0.102 & -0.582 \\
1986 & -0.150 & -0.070 & -0.560 \\
1988 & -0.146 & -0.094 & -0.518 \\
1990 & -0.123 & -0.055 & -0.545 \\
1992 & -0.195 & -0.113 & -0.593 \\
1994 & -0.180 & -0.107 & -0.557 \\
1996 & -0.128 & -0.050 & -0.543 \\
1998 & -0.089 & -0.017 & -0.513 \\
2000 & -0.064 & -0.002 & -0.534 \\
2002 & -0.161 & -0.080 & -0.531 \\
2004 & -0.200 & -0.127 & -0.584 \\
2006 & -0.142 & -0.064 & -0.558 \\
2008 & -0.124 & -0.042 & -0.534 \\
2010 & -0.218 & -0.105 & -0.561
\end{tabular}

Appendix Table 17:

Average Decline in Log Weekly Earnings, by Year and Education Full-Time Job Losers

(Numbers for Figure 17)

\begin{tabular}{r|rrrr} 
Year & $\mathrm{ED}<12$ & $\mathrm{ED}=12$ & $\mathrm{ED} 13-15$ & $\mathrm{ED} \geq 16$ \\
\hline 1984 & -0.289 & -0.160 & -0.177 & -0.133 \\
1986 & -0.246 & -0.158 & -0.105 & -0.076 \\
1988 & -0.221 & -0.148 & -0.106 & -0.117 \\
1990 & -0.119 & -0.136 & -0.109 & -0.112 \\
1992 & -0.212 & -0.181 & -0.250 & -0.127 \\
1994 & -0.147 & -0.194 & -0.183 & -0.163 \\
1996 & -0.095 & -0.100 & -0.156 & -0.144 \\
1998 & -0.109 & -0.112 & -0.097 & -0.033 \\
2000 & -0.037 & -0.047 & -0.086 & -0.069 \\
2002 & -0.191 & -0.158 & -0.160 & -0.153 \\
2004 & -0.150 & -0.197 & -0.221 & -0.198 \\
2006 & -0.116 & -0.144 & -0.161 & -0.125 \\
2008 & -0.189 & -0.108 & -0.154 & -0.080 \\
2010 & -0.180 & -0.267 & -0.207 & -0.183
\end{tabular}


Appendix Table 18:

Proportional Change in Log Real Weekly Earnings, by year Regression Adjusted Difference-in-Difference Estimates Full-Time to Full-Time Transitions (Numbers for Figure 18)

\begin{tabular}{l|rrr} 
Year & $-\Delta W_{d}$ & $\Delta W_{c}$ & $\Delta \Delta W$ \\
\hline $1981-83$ & 0.097 & 0.044 & -0.142 \\
$1983-85$ & 0.072 & 0.042 & -0.114 \\
$1985-87$ & 0.105 & 0.040 & -0.145 \\
$1987-89$ & 0.060 & 0.042 & -0.101 \\
$1989-91$ & 0.113 & 0.019 & -0.131 \\
$1991-93$ & 0.106 & -0.009 & -0.097 \\
$1993-95$ & 0.053 & 0.032 & -0.084 \\
$1995-97$ & 0.025 & 0.052 & -0.077 \\
$1997-99$ & 0.009 & 0.059 & -0.068 \\
$1999-01$ & 0.064 & 0.052 & -0.116 \\
$2001-03$ & 0.137 & 0.033 & -0.170 \\
$2003-05$ & 0.069 & 0.010 & -0.080 \\
$2005-07$ & 0.054 & -0.002 & -0.052 \\
$2007-09$ & 0.076 & 0.035 & -0.110
\end{tabular}

